\title{
Simultaneous analysis of multiple classes of antimicrobials in environmental water samples using SPE coupled with UHPLC-ESI-MS/MS and isotope dilution
}

\author{
Ngoc Han Tran ${ }^{\mathrm{a}}$, Hongjie Chen ${ }^{\mathrm{b}}$, Thanh Van Do ${ }^{\mathrm{b}}$, Martin Reinhard ${ }^{\mathrm{b}, \mathrm{c}}$, Huu Hao \\ $\mathrm{Ngo}^{\mathrm{d}}$, Yiliang $\mathrm{He}^{\mathrm{e}}$,Karina Yew-Hoong Gin ${ }^{\mathrm{a}, \mathrm{b}}$ \\ ${ }^{a}$ NUS Environmental Research Institute, National University of Singapore, 5A Engineering Drive 1, \\ T-Lab Building, Singapore 117411, Singapore \\ ${ }^{b}$ Department of Civil and Environmental Engineering, National University of Singapore, 1 \\ Engineering Drive 2, Singapore 117576, Singapore \\ ${ }^{c}$ Department of Civil Environmental Engineering, Stanford University, CA 94305, USA \\ ${ }^{d}$ School of Civil and Environmental Engineering, University of Technology Sydney, PO Box 123, \\ Broadway, NSW 2007, Australia \\ ${ }^{e}$ School of Environmental Science and Engineering, Shanghai Jiao Tong University, Shanghai \\ 200240, China
}

\section{Highlights}

- Multiple classes of antimicrobials were simultaneously quantified by UHPLC-MS/MS.

- UHPLC-MS/MS parameters for simultaneous analysis of antimicrobials were optimized.

- A tandem SPE system was used to extract antimicrobials from environmental samples.

- Matrix effects in UHPLC-MS/MS were corrected by isotope-labeled internal standards.

- Applicability of method was demonstrated by analyzing environmental water samples.

\begin{abstract}
A robust and sensitive analytical method was developed for the simultaneous analysis of 21 target antimicrobials in different environmental water samples. Both single SPE and tandem SPE cartridge systems were investigated to simultaneously extract multiple classes of antimicrobials. Experimental results showed that good extraction efficiencies (84.5-105.6\%) were observed for the vast majority of the target analytes when extraction was performed using the tandem SPE cartridge (SB+HR-X) system under an extraction $\mathrm{pH}$ of 3.0. HPLCMS/MS parameters were optimized for simultaneous analysis of all the target analytes in a single injection. Quantification of target antimicrobials in water samples was accomplished using 15 isotopically labeled internal standards (ILISs), which allowed the efficient compensation of the losses of target analytes during sample preparation and correction of matrix effects during UHPLC-MS/MS as well as instrument fluctuations in MS/MS signal intensity. Method quantification limit (MQL) for most target analytes based on SPE was below $5 \mathrm{ng} / \mathrm{L}$ for surface waters, $10 \mathrm{ng} / \mathrm{L}$ for treated wastewater effluents, and $15 \mathrm{ng} / \mathrm{L}$ for
\end{abstract}


raw wastewater. The method was successfully applied to detect and quantify the occurrence of the target analytes in raw influent, treated effluent and surface water samples.

\section{Introduction}

Antimicrobials have been widely used in both human and veterinary medicine to prevent and treat microbial infections. In addition, they have been also utilized as feed additives to promote the rate of growth of livestock and poultry animals [1] and [2]. The large amounts of antimicrobials consumed result in their occurrence in the environment. Antimicrobials can enter the environment via a number of routes, including (i) the direct discharge of animal wastewater from poultry processing, meat processing, and aquaculture [2] and [3]; (ii) discharge of treated effluents from wastewater treatment plants (WWTPs) [4] and [5]; (iii) sewer leaking/sewer overflow [6]; and (iv) runoff from manure-amended agricultural land [7] and [8]. Hitherto, the greatest concern for the release of antibiotics into the environment is the development of antibiotic resistance genes (ARGs) and bacteria (ARB) [4], [9], [10] and [11]. The prevalence and persistence of antimicrobial resistance in bacterial pathogens have become an emerging threat to public health, which reduce the therapeutic potential against human and animal pathogens [12] and [13]. Multiple genes encoding for antimicrobial resistance have often been detected in a variety of environmental compartments, including wastewater, surface water, groundwater, drinking water, sludge, soil and sediment [14], [15] and [16].

The evolution of an antimicrobial resistance gene reservoir in the environment is considered to be related to the consumption of antimicrobials in both human and veterinary medicine. Recent studies have reported that the applications of manure and treated/untreated wastewater for irrigation tend to place a positive selective pressure for development of ARB/ARG; that is why high levels of ARGs are noted in agricultural soil[13] and [17]. To date, it is assumed that antimicrobial residues in the environment directly affect terrestrial organisms, alter microbial activity and community composition in soil, and promote the development of ARGs [13] and [18]. Generally, antimicrobials are often detected in the aquatic environments at trace levels, from $\mathrm{ng} / \mathrm{L}$ to $\mu \mathrm{g} / \mathrm{L}$ levels, which are significantly lower than therapeutic levels. However, in several cases, antibiotics could be found at relatively high concentrations up to $\mathrm{mg} / \mathrm{L}$ levels [3], [19] and [20]. It is still controversial whether the development of ARG and $\mathrm{ARB}$ can take place by continuous exposure to antimicrobials in the environment at very low concentrations (i.e. $\mathrm{ng} / \mathrm{L}$ or $\mu \mathrm{g} / \mathrm{L}$ ) over the long-term. To better understand the relationship between the evolution of $\mathrm{ARG} / \mathrm{ARB}$ and the existence of antimicrobial residues in the environment, the development of a robust and sensitive method for the determination of antimicrobials is critically needed.

Antimicrobials are often present at low concentrations in the complexity of environmental matrices and have diverse physicochemical properties (i.e. $\log K o w$ and $\mathrm{pKa}$ ). These factors make it difficult to establish a rapid and sensitive analytical method for the simultaneous determination of multiple classes of antimicrobials in environmental samples. Till now, numerous efforts have been made to develop analytical methods for determining antimicrobials in the environment [21], [22], [23], [24], [25], [26], [27] and [28]. However, 
the most common issues challenging in the establishment of analytical methods are related to extraction efficiencies of analytes and matrix effects due to the large amount of natural organic matter in the samples [21], [26] and [27]. The presence of such environmental matrices may result in reducing the extraction efficiency and hindering detection sensitivity. For example, Gómez et al. [27] found a significantly high signal suppression (84\%) that was observed for erythromycin when establishing an analytical method based on solid phase extraction (SPE) coupled with liquid chromatography tandem mass spectrometry (LCMS/MS). In most previous studies, matrix effects are usually corrected using matrix-matched standards calibration [21], [26],[27], [29] and [30]. However, this approach is really challenging to apply in routine monitoring for environmental aqueous samples, due to their different origin and matrix composition, the latter varying significantly with time in some cases. In such cases, the selection of a representative blank with a matrix composition similar to the samples is almost impossible. Hence, accuracies of the analytical methods based on matrix-matched standards calibration approach are often limited.

To date, although many methods have been developed for the determination of antimicrobials, most of the developed methods have exhibited several limitations. For instance, most developed methods have focused only on several antimicrobials or a small number of antimicrobial classes [7], [27], [29], [31] and [32]. In addition, the losses of analytes during sample preparation and matrix effects on the signal intensity during HPLCMS/MS in the majority of developed methods have been not corrected by isotopically labeled internal/surrogate standards (ILISs) [21], [26], [27], [29], [30] and [33].

Therefore, to fill these gaps, this study successfully developed a robust and sensitive method for the simultaneous determination of 21 antimicrobials belonging to 10 different classes by using tandem SPE coupled with UHPLC-MS/MS and isotope dilution. The use of tandem SPE cartridge system for simultaneous extraction is assumed to obtain acceptable recoveries for all the target analytes. The losses of analytes during SPE and matrix effects during UHPLC-MS/MS are expected to be corrected efficiently by using 15 ILISs.

\section{Experimental}

\subsection{Chemicals and reagents}

The target analytes studied in this study were 20 antibiotics and 2 antimicrobials belonging to 10 different classes, including:

(i) $\beta$-lactams: ceftazidime [CFZ], meropenem [MER], and amoxicillin [AMX].

(ii) Fluoroquinolone: ciprofloxacin [CIPX].

(iii) Lincosamides: lincomycin [LIN] and clindamycin [CLI].

(iv) Macrolides: erythromycin [ERY], azithromycin [AZT], clarithromycin [CLAR], and tylosin [TYL].

(v) Sulfonamides: sulfamethazine [SMZ] and sulfamethoxazole [SMX].

(vi) Reductase inhibitor: trimethoprim [TMP].

(vii) Tetracycline family: tetracycline [TET], minocycline [MIN], chlortetracycline [CTC], and oxytetracycline [OXY]. 
(viii) Glycopeptide: vancomycin [VCM].

(ix) Chloramphenicol [CAP].

(x) Antiseptics: triclosan [TCS] and triclocarban [TCC].

The physicochemical properties of these 21 compounds are presented in Table A.1 (Supplementary Information). All the target antibiotics and antimicrobials used in this study were of high purity grade $(>99.9 \%)$ and purchased from Sigma-Aldrich (Sigma Aldrich, Singapore). Fifteen ${ }^{2} \mathrm{H}$ and ${ }^{13} \mathrm{C}$-isotope labeled internal/surrogate standards were purchased from Toronto Research Chemicals (Toronto, Canada). The isotopically labeled surrogate/internal standards included ceftazidime- $\mathrm{d}_{5}\left[\mathrm{CFZ}-\mathrm{d}_{5}\right]$, meropenem- $\mathrm{d}_{6}\left[\mathrm{MER}-\mathrm{d}_{6}\right]$, ciprofloxacin- $\mathrm{d}_{8}\left[\mathrm{CIPX}-\mathrm{d}_{8}\right]$, lincomycin- $\mathrm{d}_{3}\left[\mathrm{LIN}-\mathrm{d}_{3}\right]$, clindamycin- $\mathrm{d}_{3}\left[\mathrm{CLI}-\mathrm{d}_{3}\right]$, azithromycin$\mathrm{d}_{3}\left[\right.$ AZT- $\left.\mathrm{d}_{3}\right]$, clarithromycin- $\mathrm{d}_{3}\left[\mathrm{CLAR}-\mathrm{d}_{3}\right]$, erythromycin- $\mathrm{d}_{6}\left[\right.$ ERY $\left.-\mathrm{d}_{6}\right]$, sulfamethazine$\mathrm{d}_{4}\left[\mathrm{SMZ}-\mathrm{d}_{4}\right]$, sulfamethoxazole- $\mathrm{d}_{4}\left[\mathrm{SMX}-\mathrm{d}_{4}\right]$, trimethoprim- $\mathrm{d}_{3}\left[\mathrm{TMP}-\mathrm{d}_{3}\right]$, tetracycline$\mathrm{d}_{6}\left[\right.$ TET- $\left.\mathrm{d}_{6}\right]$, chloramphenicol- $\mathrm{d}_{5}\left[\mathrm{CAP}-\mathrm{d}_{5}\right]$, triclosan- $\mathrm{d}_{3}\left[\right.$ TCS- $\left.\mathrm{d}_{3}\right]$, and triclocarban${ }^{13} \mathrm{C}_{6}\left[\mathrm{TCC}-{ }^{13} \mathrm{C}_{6}\right]$.

In addition, other chemical reagents and solvents, such as HPLC grade methanol, acetone, and acetonitrile, formic acid and ammonium acetate, are of high purity grade. An individual stock solution of the target antibiotics/antimicrobials and their isotopically labeled compounds was prepared in a 50:50 (v/v) mixture of methanol and Milli-Q water. The stock solutions were stored in a dark room at $-20^{\circ} \mathrm{C}$. A mixture of all target antibiotics and antimicrobials was prepared weekly by diluting individual stock solution in methanol-water $(50: 50, \mathrm{v} / \mathrm{v})$ and stored at $-20^{\circ} \mathrm{C}$. Meanwhile, a separate mixture of isotopically labeled standards (ILIS) used for internal quantification was prepared in a 50:50 (v/v) mixture of methanol and Milli-Q water and stored at $-20{ }^{\circ} \mathrm{C}$.

\subsection{Sample collections and pretreatment}

For method development, grab samples of raw and treated wastewater samples were collected from a biological wastewater treatment plant (WWTP) with activated sludge processes. The WWTP comprises of primary setting tanks, anoxic tanks, aerobic tanks, and secondary setting tanks. For surface water, grab samples were collected from a local water catchment and used for method development and validation. All water samples were filled in $1 \mathrm{~L}$ amber glass bottles and immediately carried to the laboratory in ice-packed containers. Once samples arrived at the laboratory, the samples were immediately filtered using $1.2 \mu \mathrm{m}$ glass fiber filters (GF/C, Whatman, UK), followed by $0.45 \mu \mathrm{m}$ membrane filters (PALL, corporation, US). Subsequently, the filtrate samples were spiked with a constant amount of ILISs (100 ng) before doing SPE in the same day. However, the filtrate samples spiked with a constant amount of ILISs (100 ng) could also be stored in a dark room at $4{ }^{\circ} \mathrm{C}$ until solid phase extraction (SPE) was performed, but no later than $24 \mathrm{~h}$ after the collection to minimize the degradation/hydrolysis of target analytes, particularly in terms of beta-lactam antibiotics that have been reported to be hydrolyzed under ambient water conditions [34]. The addition of ILISs to the filtered water samples before storage at $4{ }^{\circ} \mathrm{C}$ allows compensation of the hydrolysis/degradation and the loss of target analytes during the storage period of water samples as well as SPE process. 


\subsection{Direct injection}

For direct injection, $0.95 \mathrm{~mL}$ of the filtered water samples $(0.45 \mu \mathrm{m})$ was transferred into amber auto-sampler vials $(2.0 \mathrm{~mL})$ and spiked with $50 \mu \mathrm{L}$ of ILISs to achieve a final concentration of $100 \mathrm{ng} / \mathrm{mL}$. The addition of ILISs allows for the correction of matrix effects for UHPLC-ESI-MS/MS. For determination of analytes in environmental samples with concentration significantly lower than their instrumental detection limits (IQLs), it would be necessary to perform solid phase extraction (SPE) before UHPLC-MS/MS analyses.

\subsection{Solid phase extraction}

In the present study, the three kinds of SPE cartridges, including Chromabond ${ }^{\circledR} \mathrm{HR}-\mathrm{X}$ $(500 \mathrm{mg}, 6 \mathrm{~mL})$ [HR-X], Chromabond ${ }^{\circledR} \mathrm{SB}(500 \mathrm{mg}, 6 \mathrm{~mL})$ [SB], and Oasis HLB (200 mg, $6 \mathrm{~mL}$ ) [HLB], were preliminarily tested before choosing suitable SPE cartridges for simultaneous extraction of the analytes in real environmental samples. The characteristics of these SPE cartridges are presented in Table A.2 (Supplementary Information). Briefly, Oasis HLB cartridge with sorbent materials are hydrophilic N-vinylpyrrolidone and lipophilic divinylbenzene (PVP-DVB) with macro-porous structure (i.e. specific surface area up to $801 \mathrm{~m}^{2} / \mathrm{g}$ ). Chromabond ${ }^{\circledR}$ HR-X with sorbent materials are polystyrene-divinylbenzen (PSDVB) with super-crosslinked structure (specific surface area up to $1061 \mathrm{~m}^{2} / \mathrm{g}$ ) that are often applied to extract polar pollutants from environmental samples. Chromabond ${ }^{\circledR} \mathrm{SB}$ with sorbent materials are strong anion exchange resin with specific surface area up to $500 \mathrm{~m}^{2} / \mathrm{g}$.

To evaluate the extraction efficiencies of the SPE cartridges for the target analytes as well as the labeled analogues of the target analytes as surrogate/internal standards (ILISs), a series of extraction experiments were conducted by spiking the target analytes into Milli-Q water, surface water, treated wastewater effluent, and raw wastewater samples to achieve a final concentration of the target analytes in Milli-Q water $(250 \mathrm{ng} / \mathrm{L})$, surface water $(500 \mathrm{ng} / \mathrm{L})$, treated wastewater $(1000 \mathrm{ng} / \mathrm{L})$ and raw wastewater $(2000 \mathrm{ng} / \mathrm{L})$. To compensate the loss of the target analytes during extraction, a constant amount (100 ng) of ILISs, including CFZ- $\mathrm{d}_{5}$, MER-d ${ }_{6}$, CIPX-d $\mathrm{d}_{8}$, LIN-d ${ }_{3}$, CLI-d $\mathrm{d}_{3}$, AZT- $\mathrm{d}_{3}$, CLAR-d ${ }_{3}$, ERY-d $\mathrm{d}_{6}, \mathrm{SMZ- \textrm {d } _ { 4 } , \text { SMX-d }}$, TMP-d ${ }_{3}$, TET- $\mathrm{d}_{6}, \mathrm{CAP}-\mathrm{d}_{5}, \mathrm{TCS}-\mathrm{d}_{3}$, and TCC- ${ }^{13} \mathrm{C}_{6}$, were added to each water sample before the water sample was loaded onto SPE cartridges. Prior to SPE, a constant amount of $\mathrm{Na}_{4}$ EDTA $(250 \mathrm{mg}$ ) was added to each environmental water sample in order to prevent the formation of a complex of the target analytes and residual metal ions. In this study, the effects of sample $\mathrm{pH}$ values on extraction efficiencies of target compounds in Milli-Q water samples were also examined at two $\mathrm{pH}$ values ( $\mathrm{pH} 3.0$ and 7.0).

\subsubsection{Single SPE procedure}

For single SPE systems, the investigated SPE cartridges were preconditioned with $5 \mathrm{~mL}$ methanol, followed by $5 \mathrm{~mL}$ of acidified Milli-Q water ( $\mathrm{pH} \mathrm{3.0)}$ at a flow rate of $3 \mathrm{~mL} / \mathrm{min}$. Subsequently, $100 \mathrm{~mL}$ raw wastewater or $250 \mathrm{~mL}$ treated effluent or $500 \mathrm{~mL}$ surface water samples, which were earlier added by a constant amount of ILISs (100 ng) and acidified to $\mathrm{pH} 3.0$, were loaded onto the cartridges at a flow rate of $5 \mathrm{~mL} / \mathrm{min}$. After all water samples 
were passed through SPE cartridges, the cartridges were rinsed with $5 \mathrm{~mL}$ of acidified Milli$\mathrm{Q}$ water ( $\mathrm{pH} 3.0$ ) in order to remove weakly bound impurities and $\mathrm{Na}_{4}$ EDTA. Before elution, the SPE cartridges were dried for $30 \mathrm{~min}$ under vacuum. Elution of the target analytes and their ILISs from the SPE cartridges were implemented using $5 \mathrm{~mL}$ methanol, followed by $5 \mathrm{~mL}$ of a mixture of methanol-acetone (50:50, v/v) at a flow rate of $1 \mathrm{~mL} / \mathrm{min}$. The resulting extracts containing the target analytes and their ILISs were dried under a gentle stream of nitrogen at $35{ }^{\circ} \mathrm{C}$. The dried extracts were finally dissolved again with $1 \mathrm{~mL}$ of a mixture of methanol and Milli-Q water (50:50, v/v). The final aliquots were transferred into $2 \mathrm{~mL}$ amber vials and stored at $-20^{\circ} \mathrm{C}$ until UHPLC-MS/MS analyses.

\subsubsection{Tandem-SPE procedure}

For the tandem SPE system, the combination of SB and HR-X cartridges in tandem was examined. The SB cartridges were placed on top of HR-X cartridges. It is noted that both the cartridges in a tandem-SPE system were preconditioned separately before they were combined with each other to form a tandem SPE system. The precondition procedures for these SPE cartridges were the same as the cartridges mentioned in the single SPE systems. After precondition, water samples were loaded and passed through both SPE cartridges at a flow rate of $5 \mathrm{~mL} / \mathrm{min}$. After extraction, $\mathrm{SB}$ and $\mathrm{HR}-\mathrm{X}$ cartridges were separately rinsed with $5 \mathrm{~mL}$ acidified Milli-Q water and dried under vacuum for $30 \mathrm{~min}$. For elution, the target analytes and their ILIS possibly retained in the SB cartridge were eluted first by $5 \mathrm{~mL}$ methanol, followed by $5 \mathrm{~mL}$ of a mixture of methanol-acetone $(50: 50, \mathrm{v} / \mathrm{v})$ at a flow rate of $1 \mathrm{~mL} / \mathrm{min}$. Then $10 \mathrm{~mL}$ of the resulting extract was used as the solvent to elute target analytes and their ILISs retained in the HR-X cartridge. The final eluates were dried under a gentle stream of nitrogen at $35^{\circ} \mathrm{C}$. Similarly, the dried extracts finally were dissolved again with $1 \mathrm{~mL}$ of a mixture of methanol-Milli-Q water $(50: 50, \mathrm{v} / \mathrm{v})$. The final aliquots were transferred into $2 \mathrm{~mL}$ amber vials and stored at $-20^{\circ} \mathrm{C}$ until UHPLC-MS/MS analyses.

\subsection{UHPLC-ESI-MS/MS analysis}

The measurement of the target analytes was performed using ultra-high performance liquid chromatography (UHPLC, Agilent 1290 Infinity, USA) coupled with tandem mass spectrometry (MS/MS, Agilent 6490 Triple Quadrupole, USA) and isotope dilution. Agilent Poroshell 120 EC-C18 $(3.0 \times 100 \mathrm{~mm}, 2.7 \mu \mathrm{m})$ column was used to separate and quantify the target analytes and their ILISs. In this study, a combined method was used for identification and quantification of the 21 target analytes in environmental water samples by a single injection. All the target analytes and their ILISs were separated using gradient method and the following mobile phase compositions optimized: $0.1 \%$ formic acid in Milli-Q water (mobile phase A) and 0.1\% formic acid in a 50:50 (v/v) mixture of methanol and acetonitrile (mobile phase B). The gradient program started with $10 \%$ mobile phase B and kept isocratic for $1.5 \mathrm{~min}$, and then rose to $90 \%$ mobile phase B at $15 \mathrm{~min}$ and held until $22 \mathrm{~min}$. At the end of the chromatographic run, the column was re-equilibrated to the initial condition in $0.5 \mathrm{~min}$ and stabilized for $3 \mathrm{~min}$. The total mobile phase flow rate was $0.45 \mathrm{~mL} / \mathrm{min}$. This flow rate 
was chosen for optimal separation during method development and kept constant thereafter. The column and auto-sampler temperatures were kept at room temperature $(24 \pm 2)$ and $6{ }^{\circ} \mathrm{C}$, respectively. An injection volume of $10 \mu \mathrm{L}$ was used for all analyses. A post-column switch was used to divert the first $1.35 \mathrm{~mL}$ eluting solution that may contain salts/weekly bound impurities out of the column to the waste and switched to the tandem MS analyses after $3.0 \mathrm{~min}$

The tandem MS analyses were performed on a triple quadrupole with iFunnel technology, which has combined the high-efficiency electron spray ionization (ESI). The tandem MS analyses were performed simultaneously in the positive ESI $(+)$ and negative ESI (-) modes. Nitrogen gas was used as the drying and collision gas. The optimum conditions for the MS system were: dry gas temperature at $200{ }^{\circ} \mathrm{C}$; dry gas flow at $14 \mathrm{~L} / \mathrm{min}$; nebulizer pressure at $20 \mathrm{psi}$; sheath gas heater temperature at $250{ }^{\circ} \mathrm{C}$; sheath gas flow at $11 \mathrm{~L} / \mathrm{min}$; nozzle voltage $1500 \mathrm{~V}$; capillary voltage at $3000 \mathrm{~V}$; fragmentation voltage at $380 \mathrm{~V}$.

\subsection{Method validation}

Calibration curves were established by injecting pooled standard solutions prepared from the standard mixtures with the addition of a constant amount (100 ng) ILISs. Calibration curves were constructed by plotting the concentrations of each target analytes versus ratios between target analyte peak area and the corresponding ILISs peak area using a linear regression analysis $(y=a x+b)$. A fifteen-point calibration curve in the range of $0.01-1000 \mathrm{ng} / \mathrm{mL}$ was generated with a satisfactory correlation coefficient $\left(\mathrm{r}^{2}>0.990\right)$

Instrumental detection limit (IDL) and instrumental quantification limit (IQL) for each analyte were determined as the minimum detectable amount of analyte giving a signal to noise ratio $(\mathrm{S} / \mathrm{N})$ of 3 and 10 , respectively. These values were determined by direct injection of decreasing amounts of the standard mixture.

Method detection limit (MDL) and method quantification limit (MQL) were determined from the spiked water samples, as the lowest observable concentration of the analyte giving signal to noise ratios of 3 and 10, respectively. For the analytes which existed initially in water samples, MDL and MQL were estimated by determining $\mathrm{S} / \mathrm{N}$ of the lowest measured concentrations and extrapolating to $\mathrm{S} / \mathrm{N}$ values of 3 and 10 , respectively, as suggested by Tran et al. [35].

Absolute SPE recovery (i.e. extraction efficiency) tests were carried out by spiking the analytes at appropriate concentrations in various water samples before SPE and in $1 \mathrm{~mL}$ of the extract, after SPE. Absolute SPE recovery was calculated by comparing the analyte concentration of samples spiked prior to and after extraction using Eq. (1) as proposed by Tran et al. [35] and Lavén et al. [36].

$$
\text { Absolute SPE recovery }(\%)=\frac{A_{\text {Pre }}-A_{\text {Non }}}{A_{\text {Post }}-A_{\text {Non }}} \times 100
$$

where $A_{P r e}$ is the measured peak area of in the sample spiked before SPE, while $A_{\text {Non }}$ is the measured peak area of the non-spiked sample. $A_{\text {Post }}$ is the measured peak area of sample 
spiked after SPE in the reconstitution step. The SPE recovery calculated represents the loss arising from SPE extraction, excluding any losses by matrix effects in ESI-MS/MS or other instrument variations. To compensate for the losses of target analytes during SPE extraction and matrix effects during HPLC-ESI-MS/MS, the ILIS were added to the water samples prior to the whole analytical procedure in this study. The efficiency of ILISs in correcting the loss of an analyte during SPE is evaluated by relative SPE recovery, which was calculated using Eq. (2).

$$
\text { Relative SPE recovery }(\%)=\frac{[\text { Absolute recovery }]_{\text {nalyte }}}{[\text { Absolute recovery }]_{\text {ILIS }}} \times 100
$$

To investigate the matrix effect (ME) on signal intensity of the analytes during ionization in the ESI source as well as the efficiency of the ILIS in correction of the ME, a known amount of the analytes (100 $\mathrm{ng}$ ) and the ILISs (100 ng) was added to sample extracts. The ME was calculated using Eq. (3) as the percentage of analyte signal suppression or enhancement.

$$
\% \mathrm{ME}=\left[1-\frac{\mathrm{A}_{\mathrm{S}}-\mathrm{A}_{\mathrm{N}}}{\mathrm{A}_{\mathrm{Sp}-\mathrm{Sol}}}\right] \times 100
$$

where $A_{S}$ is the peak area of the analyte in the sample extracts spiked with analyte standard and ILIS mixtures (100 ng). $A_{N}$ is the peak area of the analyte in the corresponding sample extracts without spiking with standard mixtures, $\mathrm{A}_{\mathrm{Sp} \text {-Sol }}$ is the peak area of the analyte in the spiking solution (100 ng) dissolved in $\mathrm{MeOH} / \mathrm{H}_{2} \mathrm{O}(50: 50, \mathrm{v} / \mathrm{v})$. The signal of the analyte is enhanced if $\mathrm{ME}<0$, whereas the signal of analyte is suppressed if $\mathrm{ME}>0$.

\subsection{Blank analyses}

In addition, to check whether there was any instrument and sample contamination that could interfere with method detection and quantification, blank control samples were examined. For instance, to determine whether there was contamination of unlabeled target analytes in the isotopically labeled internal standards, Milli-Q water blanks were spiked only with ILIS and used to check for any possible background concentration of target analytes. It is noted that none of the target analytes were detected in these spiked blanks, suggesting that the ILIS used were appropriate for this study.

To check for possible cross contamination during sample preparation, several Milli-Q water blanks were prepared and analyzed. Similarly, these blanks resulted in concentrations below their respective MDLs. In addition, a solvent blank $(\mathrm{MeOH})$ was injected at regular intervals for every ten injections. As expected, no carryover of the target analytes as well as the respective ILIS was observed.

\subsection{Statistical analysis}

An unpaired $T$-test was used to examine the statistically significant difference between mean values of two independent groups. A significance level of 0.05 was used for all statistical 
tests in this study. Minimum, maximum and median values were calculated based on detectable values and values below MDLs were set at $50 \%$ of MDLs.

\section{Results and discussion}

\subsection{Optimization of HPLC-MS/MS analysis}

The precursor and product ions of individual target analytes were identified by tuning after direct injection of $100 \mathrm{ng} / \mathrm{mL}$ in the ESI-MS/MS system that was operated under both positive and negative ionization modes to obtain the best instrument conditions for the detection of target analytes. In this study, most of the target analytes showed maximal sensitivity once operated in the positive ionization mode with the exception of six compounds, including CAP, CAP- $\mathrm{d}_{5}$, TCS, TCS- $\mathrm{d}_{3}, \mathrm{TCC}$, and TCC $-{ }^{13} \mathrm{C}_{6}$, which showed the best detection sensitivity under negative ionization mode. The protonated molecule $[\mathrm{M}+\mathrm{H}]^{+}$or deprotonated one, $[\mathrm{M}-\mathrm{H}]^{-}$were the base peak for almost target compounds, except for the cases of VCM and ERY, where the protonated molecule $[\mathrm{M}+2 \mathrm{H}]^{2+}$ and $\left[\mathrm{M}-\mathrm{H}_{2} \mathrm{O}+\mathrm{H}\right]^{+}$were the dominant peak for VCM and ERY, respectively. To date, there is still controversy about the apparent difference of $18 \mathrm{Da}$ in the precursor mass ion of ERY. This could be interpreted as a result of the loss of one molecule of water during HPLCMS/MS [37]. However, other studies revealed that this loss happened in acidic condition $(\mathrm{pH}<7.0)$ [37], [38] and [39]. For these reasons, both $734.47[\mathrm{M}+\mathrm{H}]^{+}$and 716.5 $\left[\mathrm{M}-\mathrm{H}_{2} \mathrm{O}+\mathrm{H}\right]^{+}$protonated molecules were selected as precursors ion to further detect and quantify ERY in the water samples in this study. After choosing the precursor ions, product ions were obtained and optimized with collision energy (CE) and cell accelerator voltage (CAV). Optimized ESI-MS/MS parameters for the detection of the target analytes as well as their ILISs by the multiple reaction monitoring (MRM) mode are presented in Table 1.

In addition to the optimization of MS/MS parameters, the mobile phases and composition of additives (i.e. $\mathrm{HCOOH}$ or $\mathrm{CH}_{3} \mathrm{COONH}_{4}$ ) play a significant role in obtaining reproducible retention times, satisfactory peak shapes, and good ionization efficiencies[27], [35] and [39]. In this study, different mobile phases, such as methanol $(\mathrm{MeOH})$, acetonitrile $(\mathrm{ACN})$ and a mixture of $\mathrm{MeOH}$ and $\mathrm{ACN}(50: 50, \mathrm{v} / \mathrm{v})$ with different compositions (i.e. formic acid [FA] or ammonium acetate $\left[\mathrm{NH}_{4} \mathrm{AC}\right]$ at various concentrations) were tested. As expected, the addition of FA into mobile phases resulted in good peak shapes and enhanced detection sensitivity for the majority of the target compounds and their ILISs (data not showed). However, the addition of FA in mobile phases also reduced slightly the detection sensitivity for only six of the analytes, including TCS, TCS- $\mathrm{d}_{3}$, TCC, TCC- ${ }^{13} \mathrm{C}_{6}$, CAP, and CAP- $\mathrm{d}_{5}$. Unlike $\mathrm{FA}$, the addition of $\mathrm{NH}_{4} \mathrm{AC}$ in mobile phases suppressed significantly the signal intensity of almost all antimicrobials and their ILISs. In particular, the signal peaks of AMX, CIPX, CIPX- $\mathrm{d}_{8}$, MER, MER- $\mathrm{d}_{6}, \mathrm{CFZ}$ and CFZ- $\mathrm{d}_{5}$ disappeared in the presence of only $2 \mathrm{mM}$ $\mathrm{NH}_{4} \mathrm{AC}$ in mobile phases. Finally, a gradient consisting of $0.1 \%$ FA in water (mobile phase A) and $0.1 \% \mathrm{FA}$ in a 50:50 (v/v) mixture of $\mathrm{MeOH}$ and $\mathrm{ACN}$ (mobile phase B) were chosen as appropriate mobile phases for routine HPLC-MS/MS analyses for the target compounds. 
Table 1. Optimized HPLC-ESI-MS/MS parameters for analysis of the analytes by MRM.

\begin{tabular}{|c|c|c|c|c|c|c|c|}
\hline \multirow[t]{2}{*}{ Analytes } & \multirow{2}{*}{$\begin{array}{l}\text { Retention } \\
\text { time (min) }\end{array}$} & \multirow{2}{*}{$\begin{array}{l}\text { ESI } \\
\text { mode }\end{array}$} & \multirow{2}{*}{$\begin{array}{l}\text { Precursor } \\
(\mathrm{m} / \mathrm{z})\end{array}$} & \multirow{2}{*}{$\begin{array}{l}\text { MRM } \\
\text { transitions }\end{array}$} & \multicolumn{3}{|c|}{ MS/MS parameters } \\
\hline & & & & & $\begin{array}{l}\text { Frag. } \\
\text { (V) }\end{array}$ & $\begin{array}{l}\mathrm{CE} \\
(\mathrm{eV})\end{array}$ & $\begin{array}{l}\text { CAV } \\
(\mathrm{V})\end{array}$ \\
\hline \multirow[t]{2}{*}{ CFZ } & 6.44 & Positive & $547.1[\mathrm{M}+\mathrm{H}]+$ & $547.10>468.1 \mathrm{a}$ & 380 & 10 & 5 \\
\hline & & & & $547.10>166.8$ & 380 & 28 & 5 \\
\hline CFZ-d5 & 6.49 & Positive & $\begin{array}{l}552.28 \\
{[\mathrm{M}+\mathrm{H}]+}\end{array}$ & $552.28>167 \mathrm{a}$ & 380 & 28 & 5 \\
\hline MER & 6.51 & Positive & $\begin{array}{l}384.16 \\
{[\mathrm{M}+\mathrm{H}]+}\end{array}$ & $\begin{array}{l}384.16>141.1 \mathrm{a} \\
384.16>68.1\end{array}$ & $\begin{array}{l}380 \\
380\end{array}$ & $\begin{array}{l}16 \\
48\end{array}$ & $\begin{array}{l}5 \\
5\end{array}$ \\
\hline MER-d6 & 6.49 & Positive & $\begin{array}{l}390.16 \\
{[\mathrm{M}+\mathrm{H}]+}\end{array}$ & $390.16>147.1 \mathrm{a}$ & 380 & 16 & 5 \\
\hline AMX & 5.69 & Positive & $366.0[\mathrm{M}+\mathrm{H}]+$ & $\begin{array}{l}366.0>159.9 \\
366.0>114.1 \mathrm{a}\end{array}$ & $\begin{array}{l}380 \\
380\end{array}$ & $\begin{array}{l}52 \\
40\end{array}$ & $\begin{array}{l}5 \\
5\end{array}$ \\
\hline CIPX & 8.21 & Positive & $332.1[\mathrm{M}+\mathrm{H}]+$ & $\begin{array}{l}332.1>314.1 \mathrm{a} \\
332.1>231.0\end{array}$ & $\begin{array}{l}380 \\
380\end{array}$ & $\begin{array}{l}20 \\
40\end{array}$ & $\begin{array}{l}5 \\
5\end{array}$ \\
\hline CIPX-d8 & 8.19 & Positive & $340.1[\mathrm{M}+\mathrm{H}]+$ & $340.1>322.1 \mathrm{a}$ & 380 & 20 & 5 \\
\hline LIN & 7.02 & Positive & $407.2[\mathrm{M}+\mathrm{H}]+$ & $\begin{array}{l}407.2>126.2 \mathrm{a} \\
407.2>42.1\end{array}$ & $\begin{array}{l}380 \\
380\end{array}$ & $\begin{array}{l}28 \\
80\end{array}$ & $\begin{array}{l}5 \\
5\end{array}$ \\
\hline LIN-d3 & 7.02 & Positive & $410.2[\mathrm{M}+\mathrm{H}]+$ & $\begin{array}{l}410.2>129.2 \mathrm{a} \\
410.2>45.0\end{array}$ & $\begin{array}{l}380 \\
380\end{array}$ & $\begin{array}{l}40 \\
70\end{array}$ & $\begin{array}{l}5 \\
5\end{array}$ \\
\hline CLI & 10.74 & Positive & $425.2[\mathrm{M}+\mathrm{H}]+$ & $\begin{array}{l}425.2>126.0 \mathrm{a} \\
425.2>42.1\end{array}$ & $\begin{array}{l}380 \\
380\end{array}$ & $\begin{array}{l}44 \\
80\end{array}$ & $\begin{array}{l}5 \\
5\end{array}$ \\
\hline CLI-d3 & 10.74 & Positive & $428.0[\mathrm{M}+\mathrm{H}]+$ & $\begin{array}{l}428.0>129.1 \mathrm{a} \\
428.0>72.9\end{array}$ & $\begin{array}{l}380 \\
380\end{array}$ & $\begin{array}{l}78 \\
55\end{array}$ & $\begin{array}{l}5 \\
5\end{array}$ \\
\hline \multirow[t]{2}{*}{ ERY } & 12.38 & Positive & $\begin{array}{l}734.47 \\
{[\mathrm{M}+\mathrm{H}]+}\end{array}$ & $734.47>158 \mathrm{a}$ & 380 & 37 & 5 \\
\hline & & & & $734.47>576.3$ & 380 & 20 & 5 \\
\hline \multirow[t]{2}{*}{ ERY** } & 13.27 & Positive & $\begin{array}{l}716.5 \\
{[\mathrm{M}-\mathrm{H} 2 \mathrm{O}+\mathrm{H}]+}\end{array}$ & $716.5>158 a$ & 380 & 28 & 5 \\
\hline & & & & $716.5>116$ & 380 & 48 & 5 \\
\hline \multirow[t]{2}{*}{ ERY-d6 } & 12.37 & Positive & $\begin{array}{l}740.51 \\
{[\mathrm{M}+\mathrm{H}]+}\end{array}$ & $740.51>164.2$ & 380 & 32 & 5 \\
\hline & & & & $740.51>582.4$ & 380 & 20 & 5 \\
\hline AZT & 13.91 & Positive & $749.5[\mathrm{M}+\mathrm{H}]+$ & $\begin{array}{l}749.5>158 a \\
749.5>83\end{array}$ & $\begin{array}{l}380 \\
380\end{array}$ & $\begin{array}{l}25 \\
25\end{array}$ & $\begin{array}{l}5 \\
5\end{array}$ \\
\hline AZT-d3 & 13.91 & Positive & $752.4[\mathrm{M}+\mathrm{H}]+$ & $\begin{array}{l}752.4>594.3 a \\
752.4>158.1\end{array}$ & $\begin{array}{l}380 \\
380\end{array}$ & $\begin{array}{l}36 \\
46\end{array}$ & $\begin{array}{l}5 \\
5\end{array}$ \\
\hline CLAR & 13.91 & Positive & $748.5[\mathrm{M}+\mathrm{H}]+$ & $\begin{array}{l}748.5>158.2 a \\
748.5>590.2\end{array}$ & $\begin{array}{l}380 \\
380\end{array}$ & $\begin{array}{l}32 \\
10\end{array}$ & $\begin{array}{l}5 \\
5\end{array}$ \\
\hline \multirow[t]{2}{*}{$\begin{array}{l}\text { CLAR- } \\
\text { d3 }\end{array}$} & 13.91 & Positive & $751.5[\mathrm{M}+\mathrm{H}]+$ & $751.5>161.1 \mathrm{a}$ & 380 & 31 & 5 \\
\hline & & & & $751.5>593.3$ & 380 & 18 & 5 \\
\hline
\end{tabular}




\begin{tabular}{|c|c|c|c|c|c|c|c|}
\hline \multirow[t]{2}{*}{ TYL } & 12.41 & Positive & 916.53 & $916.53>174 a$ & 380 & 48 & 5 \\
\hline & & & {$[\mathrm{M}+\mathrm{H}]+$} & $916.53>83.1$ & 380 & 80 & 5 \\
\hline \multirow{2}{*}{ SMZ } & 8.49 & Positive & $279.1[\mathrm{M}+\mathrm{H}]+$ & $279.1>92.2 \mathrm{a}$ & 380 & 32 & 5 \\
\hline & & & & $279.1>124.1$ & 380 & 24 & 5 \\
\hline \multirow[t]{2}{*}{ SMZ-d4 } & 8.43 & Positive & 283.11 & $283.11>186$ & 380 & 16 & 5 \\
\hline & & & {$[\mathrm{M}+\mathrm{H}]+$} & $283.11>96.2$ & 380 & 32 & 5 \\
\hline \multirow[t]{2}{*}{ SMX } & 9.95 & Positive & $254.1[\mathrm{M}+\mathrm{H}]+$ & $254.1>92.1 \mathrm{a}$ & 380 & 32 & 5 \\
\hline & & & & $254.1>64.9$ & 380 & 60 & 5 \\
\hline \multirow[t]{2}{*}{ SMX-d4 } & 9.94 & Positive & $258.1[\mathrm{M}+\mathrm{H}]+$ & $258.1>96.2 \mathrm{a}$ & 380 & 28 & 5 \\
\hline & & & & $258.1>112.1$ & 380 & 20 & 5 \\
\hline \multirow[t]{2}{*}{ TMP } & 7.64 & Positive & $291.2[\mathrm{M}+\mathrm{H}]+$ & $291.2>230 \mathrm{a}$ & 380 & 24 & 5 \\
\hline & & & & $291.2>260.9$ & 380 & 28 & 5 \\
\hline \multirow[t]{2}{*}{ TMP-d3 } & 7.59 & Positive & $294.2[\mathrm{M}+\mathrm{H}]+$ & $294.2>230.2 \mathrm{a}$ & 380 & 24 & 5 \\
\hline & & & & $294.2>123.1$ & 380 & 32 & 5 \\
\hline \multirow[t]{2}{*}{ TET } & 8.53 & Positive & 445.16 & $445.16>410.3 a$ & 380 & 16 & 5 \\
\hline & & & {$[\mathrm{M}+\mathrm{H}]+$} & $445.16>427.1$ & 380 & 5 & 5 \\
\hline \multirow[t]{2}{*}{ TET-d6 } & 8.51 & Positive & 451.16 & $451.16>416.3 \mathrm{a}$ & 380 & 16 & 5 \\
\hline & & & {$[\mathrm{M}+\mathrm{H}]+$} & & & & \\
\hline MIN & 7.45 & Positive & $458.3[\mathrm{M}+\mathrm{H}]+$ & $458.3>441.4 \mathrm{a}$ & 380 & 14 & 5 \\
\hline \multirow[t]{2}{*}{ CTC } & 10.17 & Positive & 479.12 & $479.12>444.1 \mathrm{a}$ & 380 & 24 & 5 \\
\hline & & & {$[\mathrm{M}+\mathrm{H}]+$} & $479.12>462.1$ & 380 & 10 & 5 \\
\hline \multirow[t]{2}{*}{ OXY } & 8.20 & Positive & $461.1[\mathrm{M}+\mathrm{H}]+$ & $461.1>443.1 \mathrm{a}$ & 380 & 5 & 5 \\
\hline & & & & $461.1>426.1$ & 380 & 15 & 5 \\
\hline \multirow[t]{2}{*}{ VCM } & 5.97 & Positive & 725.1 & $725.1>144 a$ & 380 & 11 & 5 \\
\hline & & & {$[\mathrm{M}+2 \mathrm{H}] 2+$} & $725.1>1306$ & 380 & 10 & 5 \\
\hline \multirow[t]{2}{*}{ CAP } & 11.15 & Negative & $321[\mathrm{M}-\mathrm{H}]-$ & $321.0>152 a$ & 380 & 12 & 5 \\
\hline & & & & $321.0>45.9$ & 380 & 56 & 5 \\
\hline \multirow[t]{2}{*}{ CAP-d5 } & 11.11 & Negative & 326.03 & $326.03>157.0 \mathrm{a}$ & 380 & 12 & 5 \\
\hline & & & {$[\mathrm{M}-\mathrm{H}]-$} & $326.03>261.9$ & 380 & 4 & 5 \\
\hline \multirow[t]{2}{*}{ TCS } & 17.83 & Negative & 286.94 & $286.94>35 a$ & 380 & 8 & 5 \\
\hline & & & {$[\mathrm{M}-\mathrm{H}]-$} & & & & \\
\hline \multirow[t]{2}{*}{ TCS-d3 } & 17.80 & Negative & 289.96 & $289.96>34.9 \mathrm{a}$ & 380 & 8 & 5 \\
\hline & & & {$[\mathrm{M}-\mathrm{H}]-$} & & & & \\
\hline \multirow[t]{2}{*}{ TCC } & 17.79 & Negative & 312.97 & $312.97>160 a$ & 380 & 4 & 5 \\
\hline & & & {$[\mathrm{M}-\mathrm{H}]-$} & $312.97>125.8$ & 380 & 20 & 5 \\
\hline TCC- & 17.79 & Negative & 320.53 & $320.53>161.8 \mathrm{a}$ & 380 & 8 & 5 \\
\hline $13 C 6$ & & & {$[\mathrm{M}-\mathrm{H}]-$} & $320.53>159.8$ & 380 & 12 & 5 \\
\hline
\end{tabular}

CE: collision energy (eV); CAV: cell accelerator voltage (V); Frag: fragmentation voltage (V). ERY**: indicating ERY was detected and quantified based on its precursor $716.5\left[\mathrm{M}-\mathrm{H}_{2} \mathrm{O}+\mathrm{H}\right]^{+}$.

a Product ion was used for quantification. 
To improve separation efficiency and get good peak shapes for analytes as well as ILISs, three HPLC columns were examined, including Agilent Poroshell 120 EC-C18 $(3.0 \times 100 \mathrm{~mm}$, $2.7 \mu \mathrm{m})$, Agilent ZORBAX SB-C18 $(2.1 \times 150 \mathrm{~mm}, 3.5 \mu \mathrm{m})$, and Agilent RRHD Eclipse Plus $\mathrm{C} 18(2.1 \times 100 \mathrm{~mm}, 1.8 \mu \mathrm{m})$. It can be seen from Fig. A1-A3(Supplementary Information) that among the HPLC columns tested, Agilent Poroshell 120 EC-C18 $(3.0 \times 100 \mathrm{~mm}, 2.7 \mu \mathrm{m})$ provided the best peak shape as well as separation efficiency for all the target analytes and ILISs. Fig. A.4 (Supplementary Information) shows representative chromatograms of a standard and ILIS mixture after being optimized.

For detection and quantification of most target compounds and the corresponding ILISs, two MRM transitions between precursor and the two most abundant product ions were monitored for each compound, as shown in Table 1. The highest characteristic precursor ion/product ion MRM transition was used for quantification purpose and the second one was selected to confirm the presence of the target compounds in the samples (Fig. A.4, Supplementary Information). However, several analytes, such as CFZ- $\mathrm{d}_{5}$, MER- $\mathrm{d}_{6}$, CIPX- $\mathrm{d}_{8}$, TET- $\mathrm{d}_{6}, \mathrm{MIN}$, TCS, and TCS- $\mathrm{d}_{3}$, showed only one MRM transition due to their poor fragmentation during ESI ionization.

In addition to considering MRM transitions, the comparison between the chromatographic retention times of a target analyte with its isotope labeled analogue was also used as a criterion to identify the presence of the target compound in the samples.

\subsection{Instrument performance}

As aforementioned, the instrument detection limit (IDL) and instrument quantification limit (IQL) for an analyte are the minimum amounts of the analyte required to produce a signal that is distinguishable from noise level with a signal to noise ratio $(\mathrm{S} / \mathrm{N})$ of 3 and 10 , respectively. Table 2 shows IDL and IQL values of the target compounds. The IDL and IQL values for the target compounds ranged from 0.001 to $3.0 \mathrm{ng} / \mathrm{mL}$ and from 0.01 to $10 \mathrm{ng} / \mathrm{mL}$, respectively, depending upon the type of analyte. In this study, to minimize the analyte losses and the impacts of instrument fluctuation on the quantification of the target analytes, the corresponding isotope labeled surrogate/internal standards (ILISs) were added in equal amounts to both known concentration (calibration standard and quality control) and unknown concentration samples before sample preparation. In this study, fifteen ${ }^{2} \mathrm{H}$ and ${ }^{13} \mathrm{C}$-isotope labeled compounds were used to establish calibration curves for the target analytes. It is noted that for the antimicrobials, which did not have their isotope-labeled analogues, the selection of internal standard for an analyte was based on the following criteria: (i) the internal standard should be an isotope labeled compound, which shares the same or very similar physicochemical properties and chemical structure as the analyte; (ii) it should have a chromatographic retention time close to that of the analyte and should mimic the analyte in the sample treatment steps; and (iii) the internal standard should have similar extraction recovery and the same ionization mode in ESI-MS/MS. Finally, the corresponding ILISs for the target analytes are shown inTable 2. After selecting the proper ILIS for each analyte, calibration curves were established with a satisfactory correlation coefficient $\left(r^{2}>0.990\right)$, as presented in Table 2. 
Table 2. Instrument performance and validation data.

\begin{tabular}{|c|c|c|c|c|c|}
\hline \multirow{2}{*}{$\begin{array}{l}\text { Target } \\
\text { analytes }\end{array}$} & \multirow{2}{*}{$\begin{array}{l}\text { Corresponding } \\
\text { ILIS }\end{array}$} & \multirow{2}{*}{$\begin{array}{l}\text { IDL } \\
\text { (ng/mL) }\end{array}$} & \multirow{2}{*}{$\begin{array}{l}\text { IQL } \\
\text { (ng/mL) }\end{array}$} & \multicolumn{2}{|c|}{ Linearity } \\
\hline & & & & $\mathrm{R}^{2}$ & $\begin{array}{l}\text { Linear } \\
(\mathrm{ng} / \mathrm{mL})\end{array}$ \\
\hline CFZ & CFZ-d5 & 2.5 & 5.0 & 0.999 & $5-1000$ \\
\hline MER & MER-d6 & 0.15 & 0.5 & 0.995 & $0.5-1000$ \\
\hline AMX & MER-d6 & 2.5 & 5.0 & 0.991 & $5-500$ \\
\hline CIPX & CIPX-d8 & 0.1 & 0.25 & 0.995 & $0.25-1000$ \\
\hline LIN & LIN-d3 & 0.005 & 0.01 & 0.996 & $0.01-1000$ \\
\hline CLI & CLI-d3 & 0.005 & 0.01 & 0.995 & $0.01-1000$ \\
\hline ERY & ERY-d6 & 0.01 & 0.05 & 0.996 & $0.05-250$ \\
\hline ERY* & CLAR-d3 & 0.005 & 0.02 & 0.993 & $0.02-500$ \\
\hline AZT & AZT-d3 & 0.005 & 0.01 & 0.993 & $0.01-500$ \\
\hline CLAR & CLAR-d3 & 0.001 & 0.01 & 0.994 & $0.01-500$ \\
\hline TYL & AZT-d3 & 0.025 & 0.05 & 0.992 & $0.05-500$ \\
\hline SMZ & SMZ-d4 & 0.002 & 0.01 & 0.998 & $0.01-500$ \\
\hline SMX & SMX-d4 & 0.01 & 0.025 & 0.996 & $0.025-1000$ \\
\hline TMP & TMP-d3 & 0.01 & 0.025 & 0.996 & $0.025-1000$ \\
\hline TET & TET-d6 & 1.5 & 5.0 & 0.995 & $5-1000$ \\
\hline MIN & TET-d6 & 3.0 & 10 & 0.995 & $10-1000$ \\
\hline СTC & TET-d6 & 0.2 & 0.5 & 0.997 & $0.5-1000$ \\
\hline OXY & TET-d6 & 2.0 & 7.5 & 0.993 & $7.5-1000$ \\
\hline TCS & TCS-d3 & 0.1 & 0.5 & 0.999 & $0.5-1000$ \\
\hline TCC & TCC-13C6 & 0.05 & 0.25 & 0.999 & $0.25-1000$ \\
\hline VCM & CFZ-d5 & 0.5 & 2.0 & 0.993 & $2.0-500$ \\
\hline CAP & CAP-d5 & 0.03 & 0.1 & 0.992 & $0.1-1000$ \\
\hline
\end{tabular}

ERY*: indicating ERY that was detected and quantified based on precursor $716.5\left[\mathrm{M}-\mathrm{H}_{2} \mathrm{O}+\mathrm{H}\right]^{+}$.

\subsection{Enhanced solid-phase extraction efficiency}

The extraction of multiple classes of antimicrobials in environmental water samples is always challenging due to the huge differences in physicochemical properties of the target analytes, such as octanol-water partition coefficient (log Kow) and acid dissociation constants ( $\mathrm{pKa}$ ) as shown in Table A.1 (Supplementary Information). Hence, the optimization of SPE in order to achieve an acceptable recovery for all the target analytes plays a significant role in the analytical method development. In this study, three different SPE cartridges, including HR-X, HLB and SB, were investigated. Experiments were conducted using $1000 \mathrm{~mL}$ Milli-Q water spiked at $250 \mathrm{ng} / \mathrm{L}$ level of each analyte under acidic $(\mathrm{pH} 3.0)$ and neutral conditions $(\mathrm{pH}$ 7.0). It can be seen from Fig. 1(a) that significantly higher extraction efficiencies for all target analytes were observed by HR-X cartridges compared to those by HLB or SB cartridges (unpaired $T$-test, $\mathrm{p}<0.05)$. HR-X cartridges exhibited high extraction efficiencies $(>80 \%)$ under $\mathrm{pH}$ of 3.0 for the vast majority of the target analytes, except AMX, ERY, MER and VCM. In contrast, extraction efficiencies for most target analytes were found to be extremely 
low by using HLB or SB cartridges. For example, the average extraction efficiencies of lincosamides (i.e. CLI and LIN), macrolides (i.e. AZT, CLAR, ERY, ERY*, and TYL) and tetracyclines (CTC, MIN, OXY and TET) by HLB cartridges varied from 1 to $34.9 \%$. Higher extraction efficiencies by HR-X compared to those by HLB or SB cartridges might be explained by the differences in the properties (e.g. sorbent material, surface area, pore size, and amount of sorbent) of these cartridges, as shown in Table A.2 (Supplementary Information). It is evident from Fig. 1 that higher absolute SPE recoveries (i.e. extraction efficiencies) of all target analytes, except ERY, were observed under acidic conditions ( $\mathrm{pH}$ 3.0). The results are consistent with those reported in the previous literature [21], [33] and [40]. Hence, further experiments for environmental water samples should be extracted by using HR-X cartridges in a single SPE (HR-X) or tandem SPE ( $\mathrm{SB}+\mathrm{HR}-\mathrm{X})$ systems under extraction $\mathrm{pH}$ of 3.0. The combination of two types of SPE cartridge (SB and HR-X) in a tandem SPE system was expected to improve extraction efficiencies for the target compounds and reduce matrix components (i.e. humic substances) in the final eluates. Because the use of strong anion exchange cartridge (SB) would allow removing negatively charge humic substances in the environmental water samples that might suppress or enhance signal intensity of target analytes during HPLC-MS/MS analysis.

It can be seen from Fig. 1 that the tandem SPE (SB+HR-X) system gave the best extraction efficiencies for almost target analytes, presenting the average extraction efficiencies between $84.5 \%$ and $105.6 \%$ in Milli Q water samples. In particular, SPE recoveries for SMZ, SMX, and tetracyclines (i.e. CTC, MIN, OXY, and TET) were improved considerably by the tandem SPE system. Their absolute extraction efficiencies by the tandem SPE system ranged from 98 to $102 \%$, while they varied from 111.6 to $139.8 \%$ by single SPE (HR-X). This improvement might be related to the removal of matrix components in the water samples by the strong anion exchange (SB) cartridge of the tandem SPE system.

Table 3 shows the absolute SPE recoveries (i.e. extraction efficiencies) and relative SPE recoveries for the analytes in different water samples. It can be seen that absolute SPE recoveries for the majority of target analytes in environmental water samples were higher than $70 \%$. In this study, fifteen ILISs were added to the environmental water samples before the whole analytical procedure to compensate the loss of target analytes during sample preparation and correct for matrix effects on the signal in ESI source. The effectiveness of ILISs in correcting the loss of target analytes during SPE was evaluated based on relative SPE recoveries. Once relative SPE recoveries were in the range of $85-115 \%$, this indicated that the use of ILISs for correction was effective. In this study, the relative SPE recoveries of all the target analytes were in the range between $85 \%$ and $115 \%$. For instance, the relative SPE recoveries for AMX, CFZ, MER, and VCM ranged from 101.5 to $108.7 \%$ in surface waters, from 94.9 to $109.6 \%$ in treated effluents, and $96.7-116.5 \%$ in raw influents. In addition, the relative standard deviation (RSD, \%) was below $17 \%$ for all target analytes, indicating a good precision of the SPE procedure. 

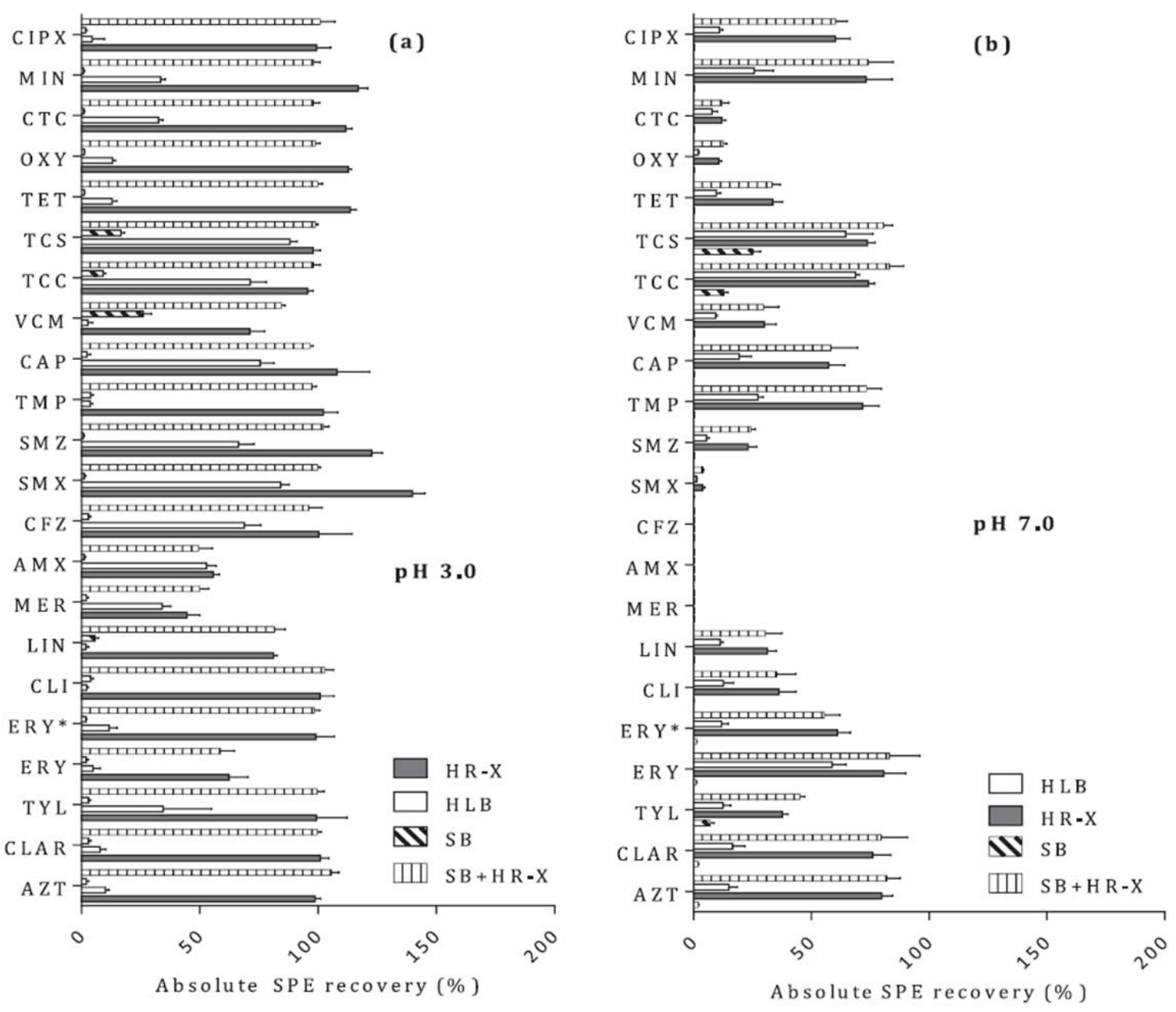

Fig. 1. Absolute SPE recovery of target analytes in Milli Q water samples enriched by SPE systems (i.e. HR-X, HLB, SB, and $\mathrm{SB}+\mathrm{HR}-\mathrm{X}$ ) under different extraction $\mathrm{pH}$ values: (a) under extraction $\mathrm{pH}$ of 3.0 and (b) under extraction $\mathrm{pH}$ of 7.0 .

\subsection{Matrix effects on method performance}

It is widely acknowledged that the main drawback of electrospray ionization mass spectrometry is its susceptibility to matrix components in environmental samples. As such, HPLC-MS/MS analysis may be subject to signal suppression or enhancement of the analytes, probably due to the presence of co-eluting matrix components in the samples [21] and [35]. For this reason, the assessment of matrix effects is crucially important to provide accurate and reproducible quantitative data. Table 4 shows the results of matrix effects on the signal intensity of the analytes. As expected, matrix effects in environmental water samples (i.e. surface waters, treated effluents, and raw influents) were higher than those in Milli-Q water samples. The absolute matrix effects (ME) narrowly ranged from -7.6 to $8.2 \%$ in Milli-Q water, while they varied broadly from -23.4 to $32.7 \%$ in surface waters, from -21.7 to $31.5 \%$ in treated effluents, and from -21.9 to $35 \%$ in raw influents. For the overwhelming majority 
of target analytes, matrix effects resulted in suppression of signal intensity. However, signal enhancement was noted for tetracyclines (i.e. TET, MIN, and OXY) in both Milli-Q water and environmental water samples. To correct for matrix effects in the quantification of the target analytes, 15 ILISs were used for correcting signal suppression or enhancement. Generally, all the target analytes were corrected efficiently in all environmental matrices. For example, TCC suffered 35\% absolute signal suppression in raw influent samples; but when using $\mathrm{TCC}-{ }^{13} \mathrm{C}_{6}$ to correct matrix effects, the signal suppression reduced to $1.1 \%$ relative suppression.

Table 3. Absolute and relative SPE recoveries of the analytes in various environmental samples using the tandem SPE (SB+HR-X) system under extraction $\mathrm{pH}$ of 3.0.

\begin{tabular}{|c|c|c|c|c|c|c|c|c|}
\hline \multirow{2}{*}{$\begin{array}{l}\text { Target } \\
\text { analyte }\end{array}$} & \multicolumn{4}{|c|}{ Absolute SPE recovery, Mean \pm RSD (\%) } & \multicolumn{4}{|c|}{ Relative SPE recovery, Mean \pm RSD (\%) } \\
\hline & $\begin{array}{l}\text { Milli-Q } \\
\text { water } \\
(n=3)\end{array}$ & $\begin{array}{l}\text { Surface } \\
\text { waters } \\
(n=3)\end{array}$ & $\begin{array}{l}\text { Treated } \\
\text { effluent } \\
(n=3)\end{array}$ & $\begin{array}{l}\text { Raw } \\
\text { influent } \\
(n=3)\end{array}$ & $\begin{array}{l}\text { Milli-Q } \\
\text { water } \\
(n=3)\end{array}$ & $\begin{array}{l}\text { Surface } \\
\text { waters } \\
(n=3)\end{array}$ & $\begin{array}{l}\text { Treated } \\
\text { effluent } \\
(n=3)\end{array}$ & $\begin{array}{l}\text { Raw } \\
\text { influent } \\
(n=3)\end{array}$ \\
\hline CFZ & $70.7 \pm 5.9$ & $66.4 \pm 6.8$ & $67.8 \pm 4.4$ & $62.7 \pm 3.4$ & $101.7 \pm 1.7$ & $101.5 \pm 5.7$ & $101.3 \pm 7.1$ & $96.7 \pm 3.9$ \\
\hline MER & $50 \pm 7.7$ & $49.8 \pm 4.9$ & $47.1 \pm 7.9$ & $46.8 \pm 6.3$ & $99.5 \pm 5.9$ & $102.1 \pm 5.3$ & $95.3 \pm 1.4$ & $105.2 \pm 13.2$ \\
\hline AMX & $50.1 \pm 11.7$ & $51.3 \pm 12.1$ & $47.1 \pm 14.9$ & $46.8 \pm 8.9$ & $98.8 \pm 13.9$ & $105 \pm 10.4$ & $94.9 \pm 8.0$ & $106.3 \pm 13.1$ \\
\hline CIPX & $101 \pm 6.0$ & $78.3 \pm 12.5$ & $75.8 \pm 12.2$ & $82.9 \pm 14.9$ & $101.7 \pm 6.0$ & $98.5 \pm 6.3$ & $100.2 \pm 6.8$ & $94.7 \pm 4.4$ \\
\hline LIN & $81.5 \pm 5.8$ & $82.6 \pm 10.2$ & $83.4 \pm 8.1$ & $81.8 \pm 10.9$ & $100.7 \pm 2.0$ & $100.5 \pm 10.3$ & $101.1 \pm 4.7$ & $99 \pm 5.5$ \\
\hline CLI & $102.8 \pm 3.7$ & $91.2 \pm 8.3$ & $93.9 \pm 5.8$ & $94.5 \pm 10.1$ & $107.3 \pm 10.1$ & $100.2 \pm 7.3$ & $99.3 \pm 4.9$ & $101 \pm 4.8$ \\
\hline ERY & $58.7 \pm 10.1$ & $52.6 \pm 5.2$ & $50.3 \pm 14$ & $54.6 \pm 11.9$ & $106.7 \pm 2.9$ & $97.7 \pm 8.7$ & $97.3 \pm 11.6$ & $98.7 \pm 10.4$ \\
\hline ERY* & $98.5 \pm 2.3$ & $96.6 \pm 2.4$ & $97 \pm 4.7$ & $88.7 \pm 3.2$ & $99.3 \pm 3.4$ & $98.8 \pm 5.1$ & $108 \pm 9.7$ & $94.2 \pm 10.5$ \\
\hline AZT & $105.7 \pm 2.9$ & $98.9 \pm 3.0$ & $94.8 \pm 2.6$ & $104.9 \pm 6.6$ & $102.3 \pm 2.8$ & $102.6 \pm 3.0$ & $98.9 \pm 2.3$ & $107.3 \pm 8.9$ \\
\hline CLAR & $99.8 \pm 1.6$ & $96.4 \pm 7.9$ & $84.7 \pm 10.4$ & $92.5 \pm 11.4$ & $100.5 \pm 2.4$ & $98.7 \pm 10.7$ & $99.4 \pm 5.4$ & $97.6 \pm 5.0$ \\
\hline TYL & $99.6 \pm 2.9$ & $88.6 \pm 6.4$ & $87.2 \pm 8.8$ & $85.7 \pm 8.0$ & $96.4 \pm 3.0$ & $91.9 \pm 6.9$ & $90.8 \pm 6.9$ & $87.7 \pm 3.4$ \\
\hline SMZ & $102 \pm 2.2$ & $77.6 \pm 3.0$ & $75.3 \pm 6.2$ & $74.2 \pm 8.2$ & $99.0 \pm 3.7$ & $102.8 \pm 5.8$ & $99.3 \pm 4.9$ & $102.6 \pm 9.5$ \\
\hline SMX & $99.8 \pm 1.2$ & $85.1 \pm 7.6$ & $76.6 \pm 10.2$ & $73.2 \pm 12.5$ & $98.1 \pm 3.4$ & $100.4 \pm 4.2$ & $102.6 \pm 5.3$ & $102.1 \pm 4.2$ \\
\hline TMP & $97.6 \pm 1.7$ & $98.4 \pm 3.3$ & $97.3 \pm 8.7$ & $95.1 \pm 2.8$ & $99.5 \pm 2.5$ & $99.7 \pm 7.2$ & $99.8 \pm 4.4$ & $102 \pm 4.5$ \\
\hline TET & $99.9 \pm 1.9$ & $94.7 \pm 3.3$ & $94.2 \pm 4.9$ & $98.3 \pm 4.8$ & $99.8 \pm 2.4$ & $105.9 \pm 2.9$ & $103.4 \pm 6.4$ & $104.1 \pm 1.0$ \\
\hline MIN & $98.1 \pm 2.8$ & $76.5 \pm 16.2$ & $84.3 \pm 8.8$ & $81.8 \pm 10.7$ & $98.0 \pm 2.3$ & $85.2 \pm 12.9$ & $92.3 \pm 5.4$ & $86.5 \pm 7.7$ \\
\hline CTC & $98 \pm 2.8$ & $95.7 \pm 5.5$ & $93.9 \pm 5.7$ & $95.5 \pm 2.9$ & $97.8 \pm 3.2$ & $107 \pm 11.2$ & $103.2 \pm 8.7$ & $101.1 \pm 2.5$ \\
\hline
\end{tabular}




\begin{tabular}{lccccccccc}
\hline OXY & $98.8 \pm 2.0$ & $97.2 \pm 5.3$ & $96.2 \pm 5.5$ & $97.8 \pm 9.0$ & $98.7 \pm 1.2$ & $108.9 \pm 11$ & $105.5 \pm 5.3$ & $103.6 \pm 9.4$ \\
TCS & $98.9 \pm 1.0$ & $93.7 \pm 4.5$ & $95.1 \pm 2.2$ & $85.9 \pm 11.2$ & $102.4 \pm 51$ & $101.6 \pm 4.5$ & $100.5 \pm 6.4$ & $98.9 \pm 6.7$ \\
TCC & $98 \pm 3.0$ & $93.7 \pm 6.4$ & $97.7 \pm 5.3$ & $93.1 \pm 11$ & $103 \pm 1.4$ & $102.4 \pm 4.5$ & $101.3 \pm 5.5$ & $102.9 \pm 4.4$ \\
VCM & $84.6 \pm 1.8$ & $70.9 \pm 6.6$ & $73.5 \pm 7.2$ & $75.5 \pm 5.9$ & $89.8 \pm 8.0$ & $108.7 \pm 10.1$ & $109.6 \pm 4.3$ & $116.5 \pm 1.9$ \\
CAP & $96.7 \pm 1.3$ & $92.1 \pm 2.2$ & $94.4 \pm 3.1$ & $92.7 \pm 2.1$ & $99.5 \pm 1.7$ & $100.8 \pm 3.4$ & $102.3 \pm 2.9$ & $100.3 \pm 4.4$ \\
\hline
\end{tabular}

ERY*: indicating ERY that was detected and quantified based on precursor $716.5\left[\mathrm{M}-\mathrm{H}_{2} \mathrm{O}+\mathrm{H}\right]^{+}$.

Table 4. Matrix effects (ME, \%) on the analytical method performance.

\begin{tabular}{|c|c|c|c|c|c|c|c|c|}
\hline \multirow{2}{*}{$\begin{array}{l}\text { Target } \\
\text { analyte }\end{array}$} & \multicolumn{4}{|c|}{ ME before being corrected by ILISs (\%) } & \multicolumn{4}{|c|}{ ME after being corrected by ILISs (\%) } \\
\hline & $\begin{array}{l}\text { Milli-Q } \\
\text { water } \\
(n=3)\end{array}$ & $\begin{array}{l}\text { Surface } \\
\text { waters } \\
(n=3)\end{array}$ & $\begin{array}{l}\text { Treated } \\
\text { effluent } \\
(n=3)\end{array}$ & $\begin{array}{l}\text { Raw } \\
\text { influent } \\
(\mathrm{n}=3)\end{array}$ & $\begin{array}{l}\text { Milli-Q } \\
\text { water } \\
(n=3)\end{array}$ & $\begin{array}{l}\text { Surface } \\
\text { waters } \\
(n=3)\end{array}$ & $\begin{array}{l}\text { Treated } \\
\text { effluent } \\
(n=3)\end{array}$ & $\begin{array}{l}\text { Raw } \\
\text { influent } \\
(n=3)\end{array}$ \\
\hline CFZ & $6.2 \pm 1.9$ & $22.3 \pm 3.1$ & $26.7 \pm 4.6$ & $24.9 \pm 7.9$ & $1.8 \pm 0.8$ & $0.8 \pm 0.1$ & $0.9 \pm 0.2$ & $0.9 \pm 0.1$ \\
\hline MER & $5.9 \pm 0.9$ & $19.3 \pm 2.0$ & $21.3 \pm 3.8$ & $25 \pm 2.4$ & $2.7 \pm 0.7$ & $1.2 \pm 0.3$ & $0.8 \pm 0.1$ & $1.4 \pm 0.5$ \\
\hline AMX & $5.6 \pm 1.9$ & $24.9 \pm 2.5$ & $24.1 \pm 2.8$ & $24 \pm 4.2$ & $1.6 \pm 0.6$ & $1.0 \pm 0.1$ & $0.8 \pm 0.1$ & $0.9 \pm 0.1$ \\
\hline CIPX & $3.9 \pm 1.4$ & $8.6 \pm 3.0$ & $8.1 \pm 3.3$ & $9.5 \pm 5.7$ & $0.7 \pm 0.2$ & $0.7 \pm 0.1$ & $0.6 \pm 0.2$ & $0.6 \pm 0.3$ \\
\hline LIN & $7.5 \pm 2.9$ & $18.5 \pm 3.0$ & $24.7 \pm 3.6$ & $31 \pm 3.2$ & $0.8 \pm 0.1$ & $1.6 \pm 0.4$ & $1.3 \pm 0.1$ & $1.2 \pm 0.2$ \\
\hline CLI & $5.0 \pm 2.3$ & $15.5 \pm 4.2$ & $20.8 \pm 2.9$ & $24.9 \pm 4.5$ & $1.4 \pm 0.7$ & $1.9 \pm 0.4$ & $1.0 \pm 0.2$ & $0.8 \pm 0.2$ \\
\hline ERY & $7.8 \pm 2.3$ & $32 \pm 4.4$ & $27 \pm 4.1$ & $31.7 \pm 5.8$ & $1.7 \pm 0.8$ & $1.1 \pm 0.3$ & $0.8 \pm 0.2$ & $0.8 \pm 0.4$ \\
\hline ERY* & $5.9 \pm 0.5$ & $20.7 \pm 4.9$ & $23.7 \pm 6.2$ & $26 \pm 2.0$ & $1.1 \pm 0.6$ & $1.1 \pm 0.1$ & $1.1 \pm 0.6$ & $1.1 \pm 0.2$ \\
\hline AZT & $1.6 \pm 3.4$ & $9.3 \pm 3.4$ & $11.5 \pm 4.8$ & $12.5 \pm 4.3$ & $0.3 \pm 0.7$ & $0.9 \pm 0.1$ & $0.8 \pm 0.1$ & $1.0 \pm 0.1$ \\
\hline CLAR & $5.5 \pm 1.1$ & $22.5 \pm 5.4$ & $23.8 \pm 8.1$ & $26.8 \pm 1.1$ & $1.1 \pm 0.9$ & $1.1 \pm 0.1$ & $1.0 \pm 0.1$ & $1.1 \pm 0.8$ \\
\hline TYL & $4.1 \pm 1.4$ & $11.3 \pm 4.1$ & $14.2 \pm 4.6$ & $15.9 \pm 2.1$ & $1.0 \pm 0.1$ & $1.0 \pm 0.1$ & $1.1 \pm 0.1$ & $1.3 \pm 0.5$ \\
\hline SMZ & $2.8 \pm 0.8$ & $10.8 \pm 3.2$ & $11.3 \pm 3.0$ & $14.6 \pm 6.3$ & $-2.0 \pm 0.4$ & $0.9 \pm 0.2$ & $0.9 \pm 0.1$ & $0.8 \pm 0.3$ \\
\hline SMX & $3.6 \pm 1.0$ & $13.2 \pm 3.3$ & $18.6 \pm 6.6$ & $18.9 \pm 3.0$ & $0.4 \pm 0.2$ & $1.0 \pm 0.2$ & $1.2 \pm 0.4$ & $1.2 \pm 0.2$ \\
\hline TMP & $6.2 \pm 2.2$ & $27.2 \pm 3.6$ & $20.6 \pm 4.9$ & $28.5 \pm 6.2$ & $1.8 \pm 3.4$ & $0.9 \pm 0.4$ & $1.0 \pm 0.2$ & $0.9 \pm 0.2$ \\
\hline TET & $-3.7 \pm 1.7$ & $-22.1 \pm 5.8$ & $-19.7 \pm 7.0$ & $-20.6 \pm 4.3$ & $1.2 \pm 0.9$ & $1.4 \pm 0.3$ & $0.8 \pm 0.4$ & $1.1 \pm 0.3$ \\
\hline MIN & $-4.6 \pm 1.7$ & $-19.4 \pm 6.4$ & $-16.8 \pm 6.3$ & $-18.6 \pm 3.5$ & $1.4 \pm 0.7$ & $1.3 \pm 0.3$ & $0.8 \pm 0.4$ & $1.0 \pm 0.1$ \\
\hline СТC & $-7.6 \pm 2.7$ & $-23.4 \pm 8.8$ & $-21.7 \pm 10.9$ & $-17.7 \pm 2.9$ & $2.4 \pm 1.5$ & $1.5 \pm 0.3$ & $1.0 \pm 0.6$ & $1.0 \pm 0.2$ \\
\hline OXY & $-6.1 \pm 1.4$ & $-22.9 \pm 3.2$ & $-20.9 \pm 4.1$ & $-21.9 \pm 2.0$ & $1.9 \pm 1.0$ & $1.5 \pm 0.4$ & $0.9 \pm 0.4$ & $1.2 \pm 0.2$ \\
\hline TCS & $8.6 \pm 2.4$ & $23.8 \pm 6.8$ & $25.6 \pm 9.3$ & $29.4 \pm 4.6$ & $0.8 \pm 0.1$ & $1.0 \pm 0.1$ & $1.0 \pm 0.2$ & $0.9 \pm 0.1$ \\
\hline TCC & $7.1 \pm 3.2$ & $32.7 \pm 6.3$ & $31.5 \pm 4.5$ & $35 \pm 2.6$ & $0.6 \pm 0.2$ & $1.1 \pm 0.1$ & $1.0 \pm 0.1$ & $1.1 \pm 0.2$ \\
\hline VCM & $5.4 \pm 2.0$ & $16.1 \pm 1.5$ & $17.2 \pm 2.9$ & $19.8 \pm 2.9$ & $1.6 \pm 0.9$ & $0.6 \pm 0.2$ & $0.6 \pm 0.1$ & $0.8 \pm 0.3$ \\
\hline CAP & $3.1 \pm 1.3$ & $7.5 \pm 1.6$ & $11.2 \pm 1.6$ & $12.8 \pm 2.1$ & $0.6 \pm 0.1$ & $0.8 \pm 0.1$ & $0.6 \pm 0.2$ & $0.9 \pm 0.1$ \\
\hline
\end{tabular}

ERY*: indicating ERY that was detected and quantified based on precursor $716.5\left[\mathrm{M}-\mathrm{H}_{2} \mathrm{O}+\mathrm{H}\right]^{+}$. 
In this study, TET- $\mathrm{d}_{6}$ was selected as ILIS to correct matrix effects for analytes belonging to the tetracycline family, such as CTC, OXY, and MIN. Similarly, CFZ-d $\mathrm{d}_{5}$ and MER-d ${ }_{6}$ could be used to correct matrix effects for AMX; however, MER- $\mathrm{d}_{6}$ appeared to be more efficient in correcting matrix effects than the use of CFZ- $\mathrm{d}_{5}$. Hence, MER- $\mathrm{d}_{6}$ was selected to correct for this compound in further studies. For glycopeptide antibiotic (VCM), its isotopically labeled analogues were unavailable, and a suitable ILIS needs to be chosen for correcting matrix effects. Among the 15 ILISs, CFZ- $\mathrm{d}_{5}$ appeared to be more efficient in correcting matrix effects. This is probably due to the fact that $\mathrm{pKa}$ and $\log K o w$ values of VCM are relatively close to those of CFZ. In addition, the chromatographic retention time of CFZ- $\mathrm{d}_{5}$ is also closer to that of VCM than other ILISs.

Taken together, the use of 15 ILISs proved to be efficient for correcting matrix effects without further treatments, such as diluting the extracted samples, using matrix-matched standards calibration, or the use of time-consuming and laborious quantification by standard addition for each samples and analyte investigated.

\subsection{Method detection limit (MDL) and quantification limit (MQL)}

Table 5 shows the MDL and MQL values for target analytes in different environmental water samples. The MDLs ranged from 0.02 to $15 \mathrm{ng} / \mathrm{L}$ in surface waters, and from 0.05 to $25 \mathrm{ng} / \mathrm{L}$ in treated effluents, and from 0.1 to $40 \mathrm{ng} / \mathrm{L}$ for raw influent, depending on the type of analytes and environmental matrices. It can be seen from Table 5 that MQL values of most target analytes in surface waters were below $5.0 \mathrm{ng} / \mathrm{L}$, except for $\beta$-lactam antibiotics (CFZ and AMX) and the tetracycline family (TET, MIN, CTC, and OXY). Higher values of MQLs for $\beta$-lactam antibiotics and tetracyclines could be due to their transformation (e.g. hydrolysis or complexation) during sample preparation as $\beta$-lactam antibiotics have been reported to be easily degraded in environmental water condition, especially under acidic and alkaline conditions or in the presence of weak nucleophiles (i.e. water or metal ions) [34] and [41]. Hirte et al. [34] have recently found that the half-life of AMX in water was $128.2 \mathrm{~h}$ under acidic conditions ( $\mathrm{pH} 3$ ), $208.3 \mathrm{~h}$ in neutral conditions ( $\mathrm{pH} 7$ ), and only $9.7 \mathrm{~h}$ in alkaline conditions $(\mathrm{pH} 11)$. For tetracyclines, their complex formation with divalent metal cations (i.e. $\mathrm{Mg}^{2+}, \mathrm{Ca}^{2+}$, and $\mathrm{Cu}^{2+}$ ) present in environmental water might result in their higher MQLs [42].

It was not surprising to note that MDL and MQL values in treated effluents and raw influents were higher than those in surface waters. This is probably due to the smaller volume of treated effluents $(250 \mathrm{~mL})$ and raw influents $(100 \mathrm{~mL})$ used in SPE compared to that of surface waters $(500 \mathrm{~mL})$. For direct injection, the MQL values for the analytes varied significantly from $20 \mathrm{ng} / \mathrm{L}$ to $15,500 \mathrm{ng} / \mathrm{L}$ (Table 5), depending upon the target analytes and environmental matrices. For example, direct injection based MQLs of lincosamides (CLI and LIN) and sulfonamides (SMZ and SMX) in environmental samples were relatively low, ranging from 20 to $75 \mathrm{ng} / \mathrm{L}$. In contrast, MQLs for $\beta$-lactam antibiotics (CFZ, MER, and AMX) and tetracyclines (TET, CTC, MIN, and OXY) were considerably higher $(750 \mathrm{ng} / \mathrm{L}$ to $15,000 \mathrm{ng} / \mathrm{L})$. 
Table 5. Method detection limit (MDL) and method quantification limit (MQL) of the target analytes in different environmental water samples based on SPE and direct injection.

\begin{tabular}{|c|c|c|c|c|c|c|c|c|c|}
\hline \multirow{3}{*}{$\begin{array}{l}\text { Target } \\
\text { analyte }\end{array}$} & \multicolumn{6}{|c|}{ SPE-based method } & \multirow{2}{*}{\multicolumn{2}{|c|}{$\begin{array}{l}\begin{array}{l}\text { Direct injection } \\
\text { method }\end{array} \\
\mathrm{MQL}(\mathrm{ng} / \mathrm{L})\end{array}$}} & \multirow[t]{2}{*}{ based } \\
\hline & \multicolumn{3}{|c|}{ MDL (ng/L) } & \multicolumn{3}{|c|}{ MQL (ng/L) } & & & \\
\hline & $\begin{array}{l}\text { Surface } \\
\text { waters }\end{array}$ & $\begin{array}{l}\text { Treated } \\
\text { effluent }\end{array}$ & $\begin{array}{l}\text { Raw } \\
\text { influent }\end{array}$ & $\begin{array}{l}\text { Surface } \\
\text { waters }\end{array}$ & $\begin{array}{l}\text { Treated } \\
\text { effluent }\end{array}$ & $\begin{array}{l}\text { Raw } \\
\text { influent }\end{array}$ & $\begin{array}{l}\text { Surface } \\
\text { water }\end{array}$ & $\begin{array}{l}\text { Treated } \\
\text { effluent }\end{array}$ & $\begin{array}{l}\text { Raw } \\
\text { influent }\end{array}$ \\
\hline CFZ & 15 & 25 & 40 & 50 & 75 & 125 & 10,000 & 12,500 & 12,500 \\
\hline MER & 1.0 & 2.5 & 5.0 & 5.0 & 10 & 15 & 1000 & 1250 & 1250 \\
\hline AMX & 15 & 20 & 50 & 40 & 65 & 150 & 10,000 & 10,000 & 10,000 \\
\hline CIPX & 0.5 & 0.8 & 2.0 & 1.5 & 2.5 & 5.0 & 500 & 500 & 500 \\
\hline LIN & 0.02 & 0.05 & 0.1 & 0.1 & 0.2 & 0.3 & 20 & 20 & 20 \\
\hline CLI & 0.02 & 0.05 & 0.1 & 0.1 & 0.2 & 0.3 & 20 & 20 & 20 \\
\hline ERY & 0.05 & 0.15 & 0.3 & 0.2 & 0.5 & 1.0 & 75 & 100 & 100 \\
\hline ERY* & 0.05 & 0.1 & 0.2 & 0.15 & 0.3 & 0.6 & 50 & 50 & 50 \\
\hline AZT & 0.02 & 0.08 & 0.15 & 0.1 & 0.2 & 0.5 & 50 & 50 & 50 \\
\hline CLAR & 0.03 & 0.06 & 0.15 & 0.1 & 0.2 & 0.5 & 50 & 50 & 50 \\
\hline TYL & 0.15 & 0.3 & 0.5 & 0.5 & 1.0 & 1.5 & 150 & 200 & 200 \\
\hline SMZ & 0.03 & 0.06 & 0.1 & 0.1 & 0.2 & 0.3 & 20 & 25 & 25 \\
\hline SMX & 0.05 & 0.15 & 0.2 & 0.15 & 0.5 & 0.6 & 50 & 75 & 75 \\
\hline TMP & 0.06 & 0.15 & 0.25 & 0.2 & 0.5 & 0.8 & 75 & 100 & 100 \\
\hline TET & 4.5 & 8.0 & 15 & 15 & 25 & 50 & 5000 & 7500 & 7500 \\
\hline MIN & 10 & 16 & 40 & 30 & 50 & 125 & 12,500 & 15,000 & 15,000 \\
\hline СТC & 1.0 & 1.5 & 2.5 & 3.0 & 5.0 & 7.5 & 750 & 1000 & 1000 \\
\hline OXY & 7.5 & 12 & 23 & 25 & 40 & 75 & 7500 & 10,000 & 10,000 \\
\hline TCS & 0.6 & 1.0 & 3.0 & 2.0 & 3.5 & 10 & 750 & 750 & 1,000 \\
\hline TCC & 0.3 & 0.6 & 1.4 & 1.0 & 2.0 & 4.5 & 500 & 500 & 500 \\
\hline VCM & 3.0 & 4.5 & 12 & 10 & 15 & 40 & 3500 & 5000 & 5000 \\
\hline CAP & 0.3 & 0.5 & 0.6 & 1.0 & 1.5 & 2.0 & 200 & 250 & 250 \\
\hline
\end{tabular}

ERY*: indicating ERY that was detected and quantified based on precursor 716.5 $\left[\mathrm{M}-\mathrm{H}_{2} \mathrm{O}+\mathrm{H}\right]^{+}$.

\subsection{Application to environmental water samples}

The developed method in this study was applied to the detection and quantification of 21 antimicrobials in different environmental water samples including raw influent, treated effluent, and surface waters. Monitoring results are summarized in Table 6. It is evident that a broad-spectrum of antimicrobials was detected in raw influent and treated effluent samples. In raw influent (raw wastewater) samples, 19 out of 21 target antimicrobials were detected in all raw influent samples. The concentrations of these compounds in raw influent samples 
ranged from a few tens of ng/L to a few tens of $\mu \mathrm{g} / \mathrm{L}$, depending on the type of analyte and sampling date. The most abundant antimicrobials detected in raw influent samples were glycopeptide VCM, followed by tetracyclines (i.e. CTC, TET, OXY and MIN), $\beta$-lactam (AMX), fluoroquinolone (CIPX), macrolides (AZT, CLAR, ERY, and ERY*), and other antimicrobial classes. For example, the concentrations of VCM in raw influent samples varied from 962 to $43,740 \mathrm{ng} / \mathrm{L}$, while concentrations of LIN ranged from 57.8 to $96 \mathrm{ng} / \mathrm{L}$. It was interesting to observe that the concentrations of ERY* in environmental samples were always greater than those of ERY. The difference between the concentration of ERY* and ERY indicates the presence of degradation products of ERY (i.e. ERY- $\mathrm{H}_{2} \mathrm{O}$, with molecular weight of $715 \mathrm{Da}$ ), which existed in the environmental samples due to acid-catalyzed degradation, and not the result of the loss of one water molecule during HPLC-MS/MS analysis [37]. The apparent concentrations of ERY- $\mathrm{H}_{2} \mathrm{O}$ existing in an environmental sample can be calculated based on the concentration of ERY and ERY* using the Eq. (4).

$$
\left[E R Y-\mathrm{H}_{2} \mathrm{O}\right]=\left(\left[\mathrm{ERY}^{*}\right]-[\mathrm{ERY}]\right) \times\left(\frac{715}{733}\right)
$$

where [ERY- $\left.\mathrm{H}_{2} \mathrm{O}\right],\left[E R Y^{*}\right]$ and [ERY] are the concentration of ERY- $\mathrm{H}_{2} \mathrm{O}$, ERY* and ERY (ng/L), respectively; 715 and 733 are molecular weight of ERY- $\mathrm{H}_{2} \mathrm{O}$ and $\mathrm{ERY}$, respectively.

The calculated concentrations of ERY- $\mathrm{H}_{2} \mathrm{O}$ in environmental samples are also shown inTable 6. It is evident from Table 6 that the concentrations of ERY* in surface waters were significantly higher than those of ERY. This indicates that erythromycin may be unstable in the environmental water conditions as well as in sample preparation, particularly under acidic conditions $(\mathrm{pH}<7)$. Therefore, the detection and quantification of erythromycin in environmental samples should be implemented via both ERY (based on precursor 734.5 $\left.[\mathrm{M}+\mathrm{H}]^{+}\right)$and $\mathrm{ERY} *\left(\right.$ based on its alternative precursor $\left.716.5\left[\mathrm{M}-\mathrm{H}_{2} \mathrm{O}+\mathrm{H}\right]^{+}\right)($Table 1).

In this study, both TYL and CFZ were not found in any raw influent sample, probably due to their rapid degradation or low concentration in municipal wastewater. It was noted that several target analytes (e.g. CIPX, LIN, CLI, ERY, ERY*, AZT, CLAR, SMZ, SMX, and TMP) in raw influent samples could be rapidly quantified using direct injection of filtered raw influent samples, which were mixed with ILISs into the UHPLC-MS/MS without SPE. However, when quantifying these compounds in treated effluent and surface water samples, it would be necessary to perform SPE before UHPLC-MS/MS analyses.

Similar to occurrence tendency in raw influent samples, the vast majority of target analytes, except for CFZ, TYL, VCM and CAP, were also detected at least one time in treated wastewater effluent samples. The concentrations of most target analytes in treated effluent samples were significantly lower than those in raw influent samples, indicating the WWTP removed efficiently the target antimicrobials.

In relation to surface water samples, the number of target analytes detected declined considerably and only 11 out of 21 target compounds were omnipresent in surface water samples, including CLI, LIN, ERY, ERY- $\mathrm{H}_{2} \mathrm{O}$, AZT, CLAR, SMZ, SMX, TCC, TCS, and TMP. The concentration of these analytes varied significantly from below detection limit to several hundred ng/L, depending upon each analyte, sampling point, and sampling date. 
Table 6. Concentration range of target antimicrobials in raw influent, treated effluent, and surface water samples.

\begin{tabular}{|c|c|c|c|}
\hline \multirow{2}{*}{ Target analyte } & \multicolumn{3}{|c|}{ Concentration range (ng/L) } \\
\hline & Surface waters $(\mathrm{n}=54)$ & Treated effluent $(n=8)$ & Raw influent $(\mathrm{n}=4)$ \\
\hline CFZ & $<\mathrm{MQL}$ & $<\mathrm{MQL}$ & $<\mathrm{MQL}$ \\
\hline MER & $<\mathrm{MQL}$ & $27-68$ & $264.8-433.6$ \\
\hline AMX & $<\mathrm{MQL}$ & $<\mathrm{MQL}-883$ & $1,855-10,131$ \\
\hline CIPX & $<\mathrm{MQL}$ & $5.0-421$ & $2,241-6,453$ \\
\hline LIN & $<\mathrm{MQL}-3.6$ & $12.79-62.5$ & $57.8-96$ \\
\hline CLI & $0.02-2.81$ & $2.94-4.24$ & $23.77-26.57$ \\
\hline ERY & $<\mathrm{MQL}-2.5$ & $70.2-186.6$ & $111.4-403.3$ \\
\hline ERY* & $11.8-226.5$ & $296.3-480.4$ & $710.1-1,020.2$ \\
\hline ERY-H2O & $11.5-218.5$ & $164.8-381$ & $299.3-737.0$ \\
\hline AZT & $0.2-79.2$ & $60.1-138.3$ & $1537-2951$ \\
\hline CLAR & $0.05-55.42$ & $158.8-637.1$ & $1201-1854$ \\
\hline TYL & $<\mathrm{MQL}$ & $<\mathrm{MQL}$ & $<\mathrm{MQL}$ \\
\hline SMZ & $0.05-98.9$ & $41.1-260.8$ & $449.9-1814$ \\
\hline SMX & $0.05-168.6$ & $290.2-562$ & 893.4-1389 \\
\hline TMP & $<\mathrm{MQL}-96.4$ & $60.6-178.6$ & $197.6-251.2$ \\
\hline TET & $<\mathrm{MQL}$ & $123-1526$ & $1240-12,340$ \\
\hline MIN & $<\mathrm{MQL}$ & $<\mathrm{MQL}$ & 730.9-3,808 \\
\hline CTC & $<\mathrm{MQL}$ & $505-1,986$ & $2333-15,911$ \\
\hline OXY & $<\mathrm{MQL}$ & $335-2,014$ & $1629-30,049$ \\
\hline TCS & $<\mathrm{MQL}-46.5$ & $8.4-120.8$ & $341.1-743.9$ \\
\hline TCC & $1-74.3$ & $49-263.9$ & 423.9-933.9 \\
\hline VCM & $<\mathrm{MQL}$ & $<\mathrm{MQL}$ & $962-43,740$ \\
\hline CAP & $<\mathrm{MQL}-8.0$ & $<\mathrm{MQL}$ & $62-80$ \\
\hline
\end{tabular}

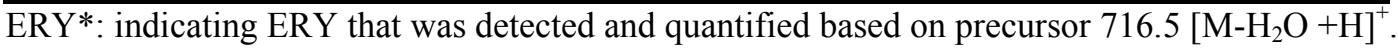
ERY-H2O is the degradation products of ERY (i.e. ERY- $\mathrm{H}_{2} \mathrm{O}$, with molecular weight of $715 \mathrm{Da}$ ), which existed in the environmental samples due to acid-catalyzed degradation, and not the result of the loss of one water molecule during HPLC-MS/MS analysis.

\section{Conclusion}

A robust and sensitive analytical method based on SPE coupled with UHPLC-MS/MS and isotope dilution was developed for the simultaneous determination of 21 antimicrobials in 
different environmental water samples. Mobile phases, mobile-phase additives, HPLC columns and MS/MS parameters were optimized for analysis. Satisfactory recoveries (84.5$105.6 \%$ ) for almost target analytes were obtained when using the tandem SPE cartridge (SB+HR-X) system for extraction. The developed analytical method was successfully validated with the different environmental water samples (i.e. surface waters, treated effluent, and raw influent). MQL value of most target antimicrobials based on SPE was below $5.0 \mathrm{ng} / \mathrm{L}$ for surface waters, $10 \mathrm{ng} / \mathrm{L}$ for treated effluents, and $15 \mathrm{ng} / \mathrm{L}$ for raw influents, which are sensitive enough to quantify the occurrence of target antimicrobials in surface waters, treated effluent and raw influent samples. This developed method was successfully applied to the routine monitoring of target antimicrobials in real environmental water samples.

\section{Acknowledgment}

This research is supported by the Singapore National Research Foundation (NRF), Prime Minister's Office, Singapore under its Campus for Research Excellence and Technological Enterprise (CREATE) programme (E2S2-CREATE project CS-B: Challenge of Emerging Contaminants on Environmental Sustainability in Megacities), administered by the NUS Environmental Research Institute (NERI). We also thank the Ministry of EducationSingapore for partial support through Grant R-302-000-088-750.

\section{References}

References

[1] K. Kümmerer, A. Henninger Clin. Microbiol. Infect., 9 (2003), pp. 1203-1214

[2] K. Kummerer Chemosphere, 75 (2009), pp. 417-434

[3] T.X. Le, Y. Munekage Mar. Pollut. Bull.

[4] L. Rizzo, C. Manaia, C. Merlin, T. Schwartz, C. Dagot, M.C. Ploy, I. Michael, D. FattaKassinos Sci. Total Environ., 447 (2013), pp. 345-360

[5] R. Andreozzi, V. Caprio, C. Ciniglia, M. De Champdore, R. Lo Giudice, R. Marotta, E. Zuccato Environ. Sci. Technol., 38 (2004), pp. 6832-6838

[6] N.H. Tran, J. Li, J. Hu, S. Ong Environ. Sci. Pollut. Res., 21 (2014), pp. 4727-4740

[7] J. Cha, A.M. Cupples Water Res., 43 (2009), pp. 2522-2530

[8] N.H. Tran, K.Y.-H. Gin, H.H. Ngo Sci. Total Environ., 538 (2015), pp. 38-57

[9] T.U. Berendonk, C.M. Manaia, C. Merlin, D. Fatta-Kassinos, E. Cytryn, F. Walsh, H. Burgmann, H. Sorum, M. Norstrom, M.N. Pons, N. Kreuzinger, P. Huovinen, S. Stefani, T. Schwartz, V. Kisand, F. Baquero, J.L. Martinez Nat. Rev. Microbiol., 13 (2015), pp. $310-317$

[10] S. Kim, D.S. Aga J. Toxicol. Environ. Health B Crit. Rev., 10 (2007), pp. 559-573 
[11] J.M. Blair, M.A. Webber, A.J. Baylay, D.O. Ogbolu, L.J. Piddock Nat. Rev. Microbiol., 13 (2015), pp. 42-51

[12] D.I. Andersson, D. Hughes Nat. Rev. Microbiol., 8 (2010), pp. 260-271

[13] Y.G. Zhu, T.A. Johnson, J.Q. Su, M. Qiao, G.X. Guo, R.D. Stedtfeld, S.A. Hashsham, J.M. Tiedje Proc. Natl. Acad. Sci. U S A, 110 (2013), pp. 3435-3440

[14] J.P. Brooks, S.L. Maxwell, C. Rensing, C.P. Gerba, I.L. Pepper Can. J. Microbiol., 53 (2007), pp. 616-622

[15] C. Xi, Y. Zhang, C.F. Marrs, W. Ye, C. Simon, B. Foxman, J. Nriagu Appl. Environ. Microbiol., 75 (2009), pp. 5714-5718

[16] M. Munir, K. Wong, I. Xagoraraki Water Res., 45 (2011), pp. 681-693

[17] M. Sun, M. Ye, J. Wu, Y. Feng, J. Wan, D. Tian, F. Shen, K. Liu, F. Hu, H. Li, X. Jiang, L. Yang, F.O. Kengara Environ. Pollut., 206 (2015), pp. 421-428

[18] M.R. Gillings, W.H. Gaze, A. Pruden, K. Smalla, J.M. Tiedje, Y.-G. Zhu ISME J., 9 (2014), pp. 1269-1279

[19] T.X. Le, Y. Munekage, S. Kato Sci. Total Environ., 349 (2005), pp. 95-105

[20] S. Managaki, A. Murata, H. Takada, B.C. Tuyen, N.H. Chiem Environ. Sci. Technol., 41 (2007), pp. 8004-8010

[21] L. Tong, P. Li, Y. Wang, K. Zhu Chemosphere, 74 (2009), pp. 1090-1097

[22] A. Boscher, C. Guignard, T. Pellet, L. Hoffmann, T. Bohn J. Chromatogr. A, 1217 (2010), pp. 6394-6404

[23] A. Gobel, C.S. McArdell, M.J. Suter, W. Giger Anal. Chem., 76 (2004), pp. 4756-4764

[24] M.J. Garcia-Galan, M.S. Diaz-Cruz, D. Barcelo Talanta, 81 (2010), pp. 355-366

[25] M.S. Diaz-Cruz, M.J. Garcia-Galan, D. Barcelo J. Chromatogr. A, 1193 (2008), pp. 5059

[26] M. Chen, Q. Yi, J. Hong, L. Zhang, K. Lin, D. Yuan Anal. Methods, 7 (2015), pp. 18961905

[27] M.J. Gómez, M. Petrovic, A.R. Fernández-Alba, D. Barceló J. Chromatogr. A, 1114 (2006), pp. 224-233

[28] M. Gros, M. Petrovic, D. Barceló Talanta, 70 (2006), pp. 678-690

[29] J.M. Cha, S. Yang, K.H. Carlson J. Chromatogr. A, 1115 (2006), pp. 46-57

[30] D. Löffler, T.A. Ternes J. Chromatogr. A, 1021 (2003), pp. 133-144

[31] S. Bayen, X. Yi, E. Segovia, Z. Zhou, B.C. Kelly J. Chromatogr. A, 1338 (2014), pp. $38-43$

[32] C. Lacey, G. McMahon, J. Bones, L. Barron, A. Morrissey, J.M. Tobin Talanta, 75 (2008), pp. 1089-1097 
[33] J. Rossmann, S. Schubert, R. Gurke, R. Oertel, W. Kirch J. Chromatogr. B Anal. Technol. Biomed. Life Sci., 969 (2014), pp. 162-170

[34] K. Hirte, B. Seiwert, G. Schuurmann, T. Reemtsma Water Res., 88 (2016), pp. 880-888

[35] N.H. Tran, J. Hu, S.L. Ong Talanta, 113 (2013), pp. 82-92

[36] M. Lavén, T. Alsberg, Y. Yu, M. Adolfsson-Erici, H. Sun J. Chromatogr. A, 1216 (2009), pp. 49-62

[37] F. Hernández, J.V. Sancho, M. Ibáñez, C. Guerrero TrAC Trends Anal. Chem., 26 (2007), pp. 466-485

[38] L.-J. Zhou, G.-G. Ying, S. Liu, J.-L. Zhao, F. Chen, R.-Q. Zhang, F.-Q. Peng, Q.-Q. Zhang J. Chromatogr. A, 1244 (2012), pp. 123-138

[39] M.S. Díaz-Cruz, D. Barceló Trac. Trends Anal. Chem., 24 (2005), pp. 645-657

[40] X. Yi, S. Bayen, B.C. Kelly, X. Li, Z. Zhou Anal. Bioanal. Chem., 407 (2015), pp. 9071-9083

[41] N. Le-Minh, S.J. Khan, J.E. Drewes, R.M. Stuetz Water Res., 44 (2010), pp. 4295-4323

[42] B. Carlotti, A. Cesaretti, F. Elisei Phys. Chem. Chem. Phys., 14 (2012), pp. 823-834 